\title{
COMMUNICATIONS
}

\section{AETIOLOGY OF UVEITIS}

\section{DENTAL INFECTION*}

BY

\section{A. STANWORTH AND H. MCINTYRE}

From the Department of Ophthalmology, University of Manchester, and the Dental Centre, Manchester Royal Infirmary

From the beginning of the 20th century, there has been a marked tendency to ascribe uveitis to focal sepsis. There are innumerable accounts in the literature of individual cases in which uveitis has been thought to be caused in this way, the evidence usually being failure to discover any other cause or improvement in the uveitis after the sepsis is treated; in addition it is occasionally possible (Amsler, 1955) to isolate the same organism both in the aqueous humour and in a focus of infection. Against these arguments must be set the failure of treatment of focal sepsis to affect the progress of a great number of cases of uveitis, the inexplicable sudden improvement that sometimes occurs in uveitis without any relationship to such treatment (Doggart, 1951), and the failure of complete or partial treatment of focal infection to influence the frequency of relapses (Guyton and Woods, 1941).

There are also numerous surveys of series of patients with uveitis; two recent surveys give the incidence of uveitis due to focal sepsis as nil (Bennett, 1955 ) and 87.5 per cent. (Alvaro, 1954), and it is possible to find published series which give almost any figure between these two extremes. In assessing the value of such surveys, the methods of investigation used are of great importance, for it is obvious that some possible causes of uveitis will be missed entirely if adequate investigation is not carried out, and it is equally obvious that some possible source of focal infection will be found in the majority of patients if adequate search is made for it, though the importance ascribed to such a focus will depend on the viewpoint of the author. In addition, the type of uveitis chosen for investigation may well radically alter the relative importance of the various possible aetiologies, and any investigation which involves only a specially selected series of patients cannot give a view of the aetiology of uveitis as a whole. Judged from this point of view, the published series fail to provide any real indication of the importance of focal sepsis.

Dental infection is commonly considered to be one of the most frequent sites of focal infection associated with uveitis (Duke-Elder, 1940), the mechanism being either direct spread via the sinuses, focal irritation, spread 
of organisms via the blood stream giving rise to direct infection in the uveal tract, or an allergic reaction to bacterial products (François, 1950). Some observers have been able to induce an iritis in animals by the injection of streptococci from dental abscesses (e.g. Rosenow, 1915; Benedict, 1920), but the iritis is usually of a purulent nature and associated with similar lesions elsewhere in the body (Woods, 1942). Though many authors incriminate all forms of dental infection in the causation of iritis, some (e.g. Bedell, 1925; Cantou, 1942) believe that only closed infective lesions of the pulp or periapical tissues are responsible, parodontal infection being of no importance; Nectoux (1947), however, considered pyorrhoea to be of great importance. Some observers consider that one criterion for the definite diagnosis of an aetiological relationship with focal sepsis is that the uveitis must be of an acute serous type (Guyton and Woods, 1941).

\section{Material and Methods}

Patients with uveitis attending the Manchester Royal Eye Hospital probably form a reasonably random selection of all patients with uveitis, since it is probable that the great majority of uveitis patients from a wide area find their way to the hospital; it is fortunate in this connexion that most general practitioners make no serious attempt to treat uveitis, but refer the patient immediately to hospital, and that many patients attend the hospital without seeing their own general practitioner at all. So far as can be ascertained, there is no particular reason why the patients attending the out-patient clinic of the University Department of Ophthalmology should not form a reasonable sample of the total attending the hospital; in particular, none of the patients in this survey was referred from any of the medical or surgical departments of the Manchester Royal Infirmary who were co-operating in the investigation.

The material comprised all new patients attending the out-patient clinic of the University Department of Ophthalmology between January, 1953, and June, 1955, who were suffering from uveitis, excluding those with frankly purulent infections (panophthalmitis), post-operative uveitis, and kerato-uveitis in which the uveitis was relatively mild and apparently dependent on the accompanying keratitis (e.g. uveitis associated with septic corneal ulcers). Those with kerato-uveitis in which the uveitis formed a major part of the disease picture, and appeared to progress independently of the keratitis, were included in the series.

The patients were routinely referred to the Dental Department, where a complete clinical and radiological examination of the teeth was performed; almost all the patients and all the radiographs were examined by one of us (H. McI.) who was unaware of the exact type of uveitis present.

Calculation of statistical probabilities $(P)$ was usually done by the $\chi^{2}$ test, using the correction for continuity. When no value of $\chi^{2}$ is given, the value of $P$ was obtained by the exact treatment of a $2 \times 2$ Table. The level of significance observed was $P \gtrless 0.05$.

\section{Definition of Terms}

Types of Uveitis.-The ocular disease diagnosed at the patient's first attendance was classified as kerato-uveitis, anterior uveitis (iritis or cyclitis, alone or together), 
posterior uveitis (choroiditis with or without cyclitis), or pan-uveitis (iritis, cyclitis, and choroiditis). Since the diagnosis of choroiditis was made only if definite choroidal lesions were seen, some patients with lens opacities or heavy vitreous opacities diagnosed as granulomatous anterior uveitis may well have been, in fact, patients with granulomatous pan-uveitis. There is, therefore, no clear-cut distinction between these groups.

The anterior uveitis group was further sub-divided into two main types: granulomatous and non-granulomatous (Woods, 1947). Many surgeons find this classification difficult to apply in practice (e.g. Davenport, 1956), and a number of patients had to be classified as of "doubtful type".

The patients were also classified into those with and those without a definitely known association with local or general disease. Such a subdivision would possibly be made in different ways by different ophthalmologists; in the present state of our ignorance only well-substantiated causes can be accepted. We have taken uveitis to be of known association with rheumatic disease when there was either radiological evidence of spondylitis, simultaneous occurrence of the three components of Reiter's disease, or uveitis with nodular sclero-keratitis associated with rheumatoid arthritis with multiple subcutaneous nodules (Stanworth and Sharp, 1956; Stanworth, 1956). The non-rheumatic diseases associated with uveitis were considered to be herpes zoster ophthalmicus, dendritic ulceration of the cornea, interstititial keratitis, secondary syphilis, sarcoidosis, sympathetic ophthalmitis, and rupture of the lens. Superficial punctate keratitis, heterochromic cyclitis, and the Vogt-Koyanagi syndrome, though considered to be non-rheumatic (Stanworth and Sharp, 1956), were not taken to be of sufficiently definite origin to justify their inclusion, from the present point of view, in the group with a known association with local or general disease.

Types of Dental Infection.-Two conditions were considered: periapical and parodontal infections. In parodontal infection there was destruction of the alveolar bone and parodontal membrane round the tooth or teeth, associated with gingival pockets. In periapical lesions there was an area of infection surrounding the apical portion of a root or a retained root. Those retained roots which appeared to be surrounded by normal bone were classified as non-infective; they were usually roots which had been retained for many years and whose presence was unsuspected on clinical examination. Those roots which had erupted through the alveolar process were considered to be infected.

\section{Results}

Table I (overleaf) shows the numbers of patients suffering from the various types of uveitis, subdivided into those with and those without a known association with local or general disease.

The group with rheumatic disease included 29 patients with spinal arthritis (22 of whom had typical ankylosing spondylitis), nine with Reiter's disease, and one with rheumatoid arthritis.

The group with non-rheumatic disease included twelve with herpes zoster ophthalmicus, four in whom the uveitis was associated in its early stages with a dendritic corneal ulcer, two with uveitis followed by the development 
TABLE I

TYPES OF UVEITIS

\begin{tabular}{|c|c|c|c|c|c|c|c|c|c|c|c|c|c|c|c|}
\hline \multirow{3}{*}{\multicolumn{2}{|c|}{$\begin{array}{l}\text { Association with Local } \\
\text { or General Disease }\end{array}$}} & \multirow{2}{*}{\multicolumn{2}{|c|}{$\begin{array}{c}\text { Kerato- } \\
\text { uveitis }\end{array}$}} & \multicolumn{6}{|c|}{ Anterior Uveitis } & \multirow{2}{*}{\multicolumn{2}{|c|}{$\begin{array}{c}\text { Posterior } \\
\text { Uveitis }\end{array}$}} & \multirow{2}{*}{\multicolumn{2}{|c|}{$\begin{array}{l}\text { Pan- } \\
\text { uveitis }\end{array}$}} & \multirow{2}{*}{\multicolumn{2}{|c|}{ Total }} \\
\hline & & & & \multicolumn{2}{|c|}{$\begin{array}{l}\text { Granulo- } \\
\text { matous }\end{array}$} & \multicolumn{2}{|c|}{$\begin{array}{l}\text { Non- } \\
\text { granulo- } \\
\text { matous }\end{array}$} & \multicolumn{2}{|c|}{ Doubtful } & & & & & & \\
\hline & & $\frac{0}{\tilde{J}}$ & 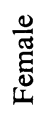 & $\frac{0}{\sum^{J}}$ & 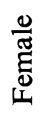 & $\frac{\infty}{\sum^{\pi}}$ & 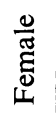 & $\frac{0}{J^{J}}$ & 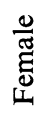 & $\frac{\stackrel{\omega}{\pi}}{\sum^{\pi}}$ & 莺 & $\frac{0}{\tilde{J}}$ & 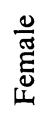 & $\frac{0}{\pi}$ & 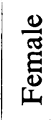 \\
\hline \multirow{3}{*}{$\begin{array}{l}\text { Known } \\
\text { Associa- } \\
\text { tion }\end{array}$} & Non-rheumatic & 8 & 7 & 2 & 2 & 3 & 1 & 1 & - & - & - & - & - & 14 & 10 \\
\hline & Rheumatic ... & - & 3 & 1 & - & 23 & 3 & 5 & 3 & - & 1 & - & 一 & 29 & 10 \\
\hline & Total & 8 & 10 & 3 & 2 & 26 & 4 & 6 & 3 & - & 1 & 一 & 一 & 43 & 20 \\
\hline \multicolumn{2}{|c|}{ No Known Association } & 8 & 9 & 11 & 35 & 32 & 28 & 12 & 8 & 9 & 19 & 2 & 1 & 74 & 100 \\
\hline & Total & 16 & 19 & 14 & 37 & 58 & 32 & 18 & 11 & 9 & 20 & 2 & 1 & 117 & 120 \\
\hline
\end{tabular}

of mild interstitial keratitis due to congenital syphilis, two with secondary syphilis, two with sarcoidosis, one with uveitis due to a rupture of the lens capsule with a slow leak of lens matter, and one with sympathetic ophthalmitis.

Table II shows that dental examination was carried out in 157 of the 174 patients without known association with local or general disease, but in only 49 of the 63 patients with such association. This relatively low figure was due mainly to the fact that only 74 per cent. of the patients with rheumatic disease were dentally examined. This was because a few patients with obvious spondylitis were not referred for dental examination; the effect of the inclusion or exclusion of such patients is discussed later.

TABLE II

INCIDENCE OF PARODONTAL AND PERIAPICAL INFECTION

\begin{tabular}{|c|c|c|c|c|c|c|c|c|c|c|}
\hline \multicolumn{3}{|c|}{$\begin{array}{l}\text { Association with Local } \\
\text { or General Disease }\end{array}$} & \multicolumn{2}{|c|}{ Examined } & \multicolumn{2}{|c|}{$\begin{array}{l}\text { Total with } \\
\text { Dental } \\
\text { Infection }\end{array}$} & \multicolumn{2}{|c|}{$\begin{array}{l}\text { Parodontal } \\
\text { Infection }\end{array}$} & \multicolumn{2}{|c|}{$\begin{array}{l}\text { Periapical } \\
\text { Infection }\end{array}$} \\
\hline & & & Male & Female & Male & Female & Male & Female & Male & Female \\
\hline \multirow{3}{*}{$\begin{array}{l}\text { Known } \\
\text { Associa- } \\
\text { tion }\end{array}$} & Non-rheumati & & 11 & 9 & 5 & 5 & 3 & 5 & 3 & 1 \\
\hline & Rheumatic & $\cdots$ & 23 & 6 & 8 & 3 & 6 & 2 & 4 & 1 \\
\hline & Total & $\cdots$ & 34 & 15 & 13 & 8 & 9 & 7 & 7 & 2 \\
\hline \multicolumn{3}{|c|}{ No Known Association } & 67 & 90 & 27 & 33 & 24 & 21 & 8 & 16 \\
\hline & Total & $\cdots$ & 101 & 105 & 40 & 41 & 33 & 28 & 15 & 18 \\
\hline
\end{tabular}

Table II also shows that there was no significant difference in the incidence of dental infection in males and females, or in those with and without a 
significant association with local or general disease; this was in accordance with the impression received during the clinical examinations that the incidence of dental disease was much the same as that in the general hospital population. The incidence of dental infection in uveitis associated with rheumatism was the same as in the whole series, and was independent of whether or not they were aware of their rheumatic disease (Table III), except perhaps for periapical infection in the age group under 41 years. This does not suggest that these patients had had any special treatment for dental infection because of their rheumatism, and, so far as parodontal infection is concerned, there is no need to eliminate them from the series. No special dental treatment had been given to any of the patients with uveitis associated with non-rheumatic disease. The incidence of dental infection (17 in 52 patients examined) in those patients who had had previous attacks of uveitis was not significantly less than that in the whole series.

TABLE III

DENTAL INFECTION IN RHEUMATIC DISEASE

\begin{tabular}{|c|c|c|c|c|c|c|}
\hline Rheumatic Disease & $\begin{array}{l}\text { Age } \\
\text { (yrs) }\end{array}$ & $\begin{array}{l}\text { No. of } \\
\text { Patients }\end{array}$ & $\begin{array}{l}\text { Number } \\
\text { Examined }\end{array}$ & $\begin{array}{l}\text { Total with } \\
\text { Dental } \\
\text { Infection }\end{array}$ & $\begin{array}{c}\text { Par- } \\
\text { odontal } \\
\text { Infection }\end{array}$ & $\begin{array}{l}\text { Periapical } \\
\text { Infection }\end{array}$ \\
\hline \multirow{2}{*}{ Known to Patient } & $\begin{array}{l}<41 \\
>40\end{array}$ & $\begin{array}{l}14 \\
13\end{array}$ & $\begin{array}{r}11 \\
8\end{array}$ & $\begin{array}{l}3 \\
5\end{array}$ & $\begin{array}{l}3 \\
3\end{array}$ & $\begin{array}{l}1 \\
2\end{array}$ \\
\hline & Total & 27 & 19 & 8 & 6 & 3 \\
\hline \multirow{2}{*}{ Not Known to Patient $\ldots$} & $\begin{array}{l}<41 \\
>40\end{array}$ & $\begin{array}{l}8 \\
4\end{array}$ & $\begin{array}{l}6 \\
4\end{array}$ & $\begin{array}{l}3 \\
1\end{array}$ & $\begin{array}{l}1 \\
1\end{array}$ & $\underline{2}$ \\
\hline & Total & 12 & 10 & 4 & 2 & 2 \\
\hline
\end{tabular}

The distribution of dental infection among the varieties of uveitis is shown in Table IV.

TABLE IV

DENTAL INFECTION IN VARIETIES OF UVEITIS

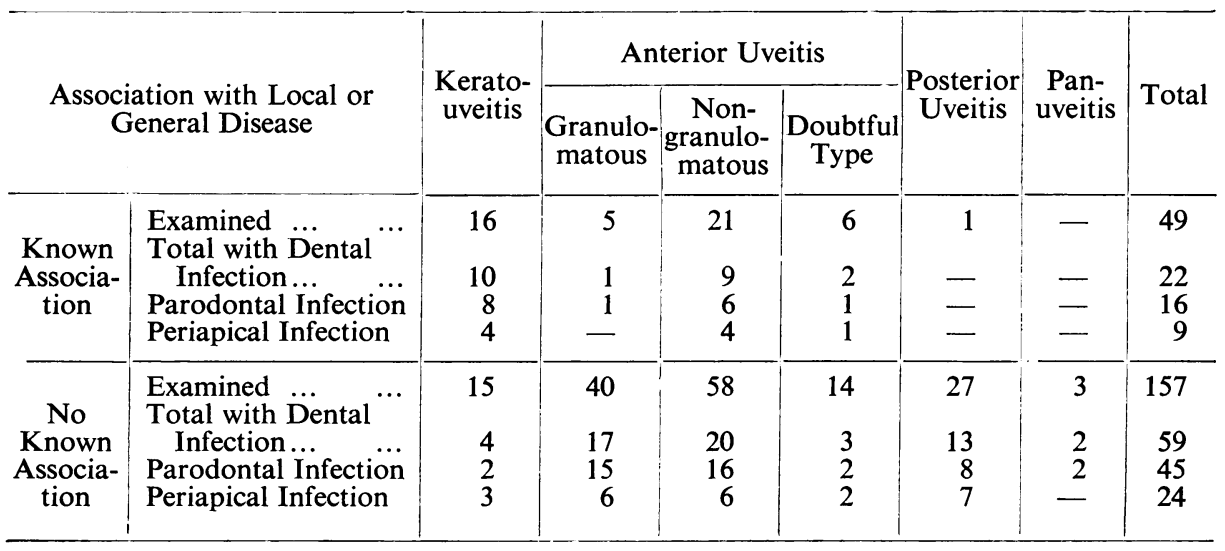


There was a slight tendency for parodontal infection to be associated with granulomatous anterior uveitis in the group of unknown aetiology, and for root infection to be associated with posterior uveitis, but neither of these tendencies was statistically significant.

Since the incidence of dental infection varies with age, it was studied in patients aged less than 21 years, $21-40$ years, $41-50$ years, and more than 50 years. There was no appreciable difference in the incidence of parodontal disease in the various types of uveitis in patients of any age group except 21-40 years, in which (Table V) there was a marked tendency for parodontal infection to occur in patients with granulomatous anterior uveitis of no known association; the difference in incidence between this group (67 per cent.) and the remainder of the series (32 per cent.) was significant $(P=0.03)$. The exclusion of patients who had had previous attacks of uveitis left the level of significance unchanged.

TABLE V

DENTAL INFECTION, AGE GROUP 21-40 YEARS

\begin{tabular}{|c|c|c|c|c|c|c|c|c|}
\hline & & & An & terior Uve & eitis & & & \\
\hline Associ & $\begin{array}{l}\text { ation with Local or } \\
\text { eneral Disease }\end{array}$ & $\begin{array}{c}\text { Kerato- } \\
\text { uveitis }\end{array}$ & $\begin{array}{c}\text { Granulo- } \\
\text { matous }\end{array}$ & $\left|\begin{array}{c}\text { Non- } \\
\text { granulo- }\end{array}\right|$ & Doubtful & $\begin{array}{c}\text { Posterior } \\
\text { Uveitis }\end{array}$ & $\begin{array}{l}\text { Pan- } \\
\text { uveitis }\end{array}$ & Total \\
\hline $\begin{array}{l}\text { Known } \\
\text { Associa- } \\
\text { tion }\end{array}$ & $\begin{array}{l}\text { Examined ... } \ldots \\
\text { Total with Dental } \\
\text { Infection ... } \ldots \\
\text { Parodontal Infection } \\
\text { Periapical Infection }\end{array}$ & $\begin{array}{l}3 \\
3 \\
1\end{array}$ & E & $\begin{array}{l}5 \\
3 \\
3\end{array}$ & $\begin{array}{l}1 \\
= \\
-\end{array}$ & E & $\begin{array}{l}- \\
=\end{array}$ & $\begin{array}{l}8 \\
6 \\
4\end{array}$ \\
\hline $\begin{array}{l}\text { No } \\
\text { Known } \\
\text { Associa- } \\
\text { tion }\end{array}$ & $\begin{array}{l}\text { Examined ... } \ldots \\
\text { Total with Dental } \\
\quad \text { Infection ... } \ldots \\
\text { Parodontal Infection } \\
\text { Periapical Infection }\end{array}$ & $\begin{array}{l}2 \\
1 \\
2\end{array}$ & $\begin{array}{r}9 \\
8 \\
4\end{array}$ & $\begin{array}{l}7 \\
5 \\
2\end{array}$ & $\begin{array}{l}2 \\
1 \\
1\end{array}$ & $\begin{array}{l}9 \\
6 \\
5\end{array}$ & E & $\begin{array}{l}29 \\
21 \\
14\end{array}$ \\
\hline
\end{tabular}

It has already been pointed out that the diagnosis of the granulomatous nature of the uveitis was not always easy, so that the classification of individual patients might vary a little with different ophthalmic surgeons. It was possible, however, to subdivide the patients with granulomatous anterior uveitis into two sub-groups: those in whom the uveitis was of an obvious chronic and granulomatous type, and those in whom these features were not so marked (Table VI, opposite). It will be seen that the incidence of parodontal infection was obviously greater in the very chronic type; if we compare the incidence in this type in the age group 21-40 years (six out of seven patients), with the incidence in the remainder of the age group (21 out of 64 patients) the difference is statistically significant $(P=0.01)$. The 
parodontal infection was generalized in three of these six patients, and there was no tendency to involve particularly the upper jaw or the mouth on the same side as the eye lesion; the infection in these patients appeared to be more generalized than in those patients with the less chronic type of uveitis.

TABLE VI

DENTAL INFECTION IN GRANULOMATOUS ANTERIOR UVEITIS OF UNKNOWN AETIOLOGY

\begin{tabular}{|c|c|c|c|c|c|}
\hline \multicolumn{3}{|c|}{ Age Group } & Chronic & $\begin{array}{c}\text { Less } \\
\text { Chronic }\end{array}$ & Total \\
\hline All Ages & $\begin{array}{l}\text { No. of Patients ... } \\
\text { No. Examined ... } \\
\text { Parodontal Infection }\end{array}$ & $\begin{array}{ll}\ldots & \ldots \\
\ldots & \ldots \\
\ldots & \ldots\end{array}$ & $\begin{array}{l}26 \\
23 \\
10\end{array}$ & $\begin{array}{r}20 \\
17 \\
5\end{array}$ & $\begin{array}{l}46 \\
40 \\
15\end{array}$ \\
\hline Age $21-40$ & $\begin{array}{l}\text { No. of Patients ... } \\
\text { No. Examined ... } \\
\text { Parodontal Infection }\end{array}$ & $\begin{array}{ll}\cdots & \cdots \\
\cdots & \cdots \\
\ldots & \cdots\end{array}$ & $\begin{array}{l}7 \\
7 \\
6\end{array}$ & $\begin{array}{l}6 \\
5 \\
2\end{array}$ & $\begin{array}{r}13 \\
12 \\
8\end{array}$ \\
\hline
\end{tabular}

It is possible that parodontal infection may also have been associated with pan-uveitis, since two of the three such patients were found to have parodontal infection, and there is no clear-cut difference in this series between granulomatous anterior uveitis and pan-uveitis.

The incidence of parodontal infection was higher ( 38 per cent.) in the age groups $21-40$ years than in the other age groups ( 25 per cent.), presumably largely because the dental state of younger people is usually good, and because in older patients parodontal sepsis tends to clear up as the teeth are lost. This may be responsible for the fact that the incidence of such infection was significant only in this age group; in other age groups, individual patients may have had uveitis genuinely associated with parodontal disease, but for most patients other factors must have been predominant.

There was a tendency in patients aged 21-40 years for there to be an increased incidence ( 38 per cent.) of root infection in posterior uveitis of unknown origin compared with that in the remainder of the series $(22$ per cent.) or in uveitis associated with local or general disease (21 per cent.). Root infection was, however, less common in those patients under the age of 41 years with rheumatic diseases of which they were aware (Table III) and, when these patients were eliminated, the incidence in patients other than those with posterior uveitis of unknown origin rose to 25 per cent. (12 patients in 47) and in patients with uveitis associated with local or general disease to 37 per cent. (three patients in eight), so that the incidence in posterior uveitis was obviously not statistically significant. 


\title{
II. UPPER RESPIRATORY TRACT AND OTHER INFECTIONS
}

\author{
BY \\ A. STANWORTH \\ Department of Ophthalmology, University of Manchester
}

THE tonsils are often considered (Duke-Elder, 1940) to be, with the teeth, the main source of focal infection responsible for uveitis, nasal sinus infection being thought to be of less importance. The significant organisms concerned are usually thought to be the various types of streptococci, and Woods $(1950,1953,1956 a)$ has made the most comprehensive study of the relationship; he found a much higher incidence ( 85 per cent.) of skin hypersensitivity to streptococcal vaccines among patients with non-granulomatous uveitis than among those with granulomatous uveitis (27 per cent.); the incidence of foci of infection was 54 and 30 per cent. respectively. The results of treatment by desensitization appeared to be good. These findings are in accordance with Wood's view that the clinical appearance and histological changes in granulomatous anterior uveitis indicate a chronically infected uveal tract, whereas those in non-granulomatous uveitis are similar to the allergic focal reactions produced in tuberculous eyes by the systemic administration of excessive amounts of tuberculin. Alvaro (1954) found that cutaneous sensitivity tests for streptococci were entirely negative in only one of 97 patients with uveitis, and ascribed uveitis to focal sepsis in 87 per cent. of patients.

As with all types of focal infection, one of the main difficulties is the frequency of upper respiratory tract infections in patients without uveitis. Apart from the skin tests already mentioned, two methods have been suggested for identifying those patients in whom the focal infection is causally related to uveitis. Harley (1952), believing that skin sensitivity reactions bore little relationship to uveal sensitivity, preferred the "pathogen selective culture", the principle of which is the "utilization of the in vitro bactericidal power of the patient's whole fresh blood to kill off organisms to which he is immune and to allow the growth of potentially pathogenic organisms, thus assisting us to select the aetiologically important organisms from a mixed culture". Dekking (1954) studied the antistreptolysin titre (A.S.T.) and agglutination tests to $\mathrm{O}$ - and L-agglutinins in the patient's serum; he considered that there was a relation between these and uveitis if certain combinations were present, namely $\mathrm{L}$ and $\mathrm{O}$ positive; high A.S.T. and $\mathrm{L}$ and $\mathrm{O}$; A.S.T. and O, or high L. High A.S.Ts. in uveitis were also found by Schöne and Steen (1951) and Smith and Ashton (1955), and, together with raised streptococcal anti-hyaluronidase titres, by Leopold and Dickinson (1954). Otten and Westendorp Boerma (1954), however, found that the A.S.Ts. and L- and O-agglutination titres were raised, not only in rheumatoid arthritis, but also in many internal diseases, such as carcinoma, hepatitis, jaundice, ulcers of the digestive tract, heart failure, and diabetes, none of which was 
associated with clinical streptococcal infection; Vesterdal (1951) found the A.S.T. to be of little value; and after further experience Hallett, Leopold, and Inwald (1956) found that streptococcal anti-hyaluronidase titres were normal in uveitis.

\section{Material and Methods}

The patients concerned, and the classification of the uveitis present, have already been described in the first paper in this series (Stanworth and McIntyre, 1957).

The patients were routinely referred for radiographs of the nasal sinuses, and those who showed any radiographic changes were referred to an Ear, Nose, and Throat surgeon for further investigation. Direct cultures were taken from the nasal vestibule and the throat, and the pathogen selective culture was also carried out on the throat swabs.

\section{Results}

Nasal Sinus Infections. - The incidence of radiographic sinus changes is shown in Table VII; there was a tendency, not quite statistically significant $\left(\chi^{2}=3.5 ; P=0.06\right)$ for there to be a greater incidence in males than in females, but this was present in the patients with a significant association with local or general disease as well as in those without, and there was no tendency for an increased incidence in all the patients with uveitis of unknown aetiology.

TABLE VII

INCIDENCE OF RADIOGRAPHIC CHANGES IN NASAL SINUSES

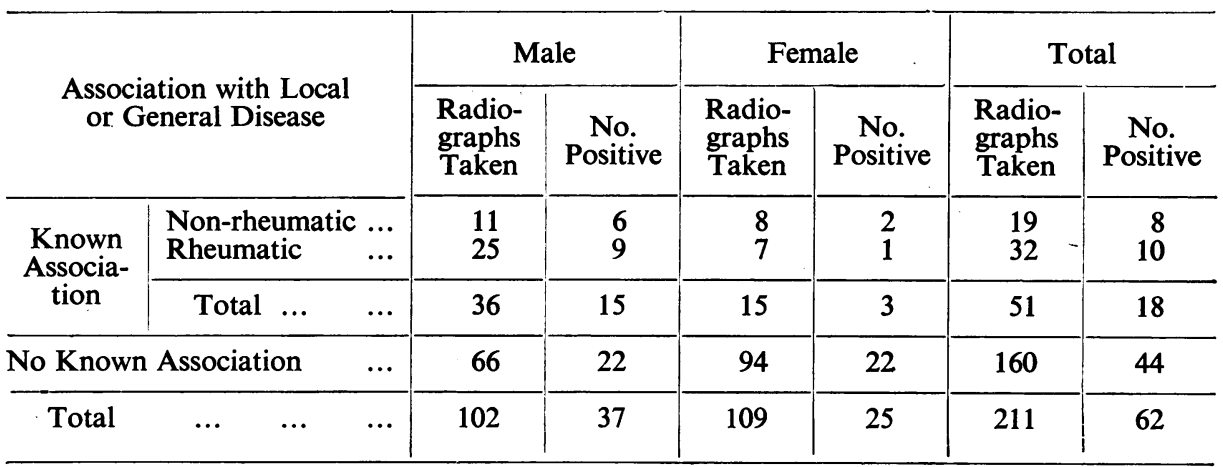

The incidence of radiographic changes was almost as great in those rheumatic patients who were aware of their disease (six out of twenty radiographs) as in those who were not aware of it (four out of twelve radiographs) and was the same as in the series as a whole; the incidence in patients who had had previous attacks of uveitis (nineteen in 54 patients) was also as great as in the whole series; there was, then, no evidence that these patients had had special treatment for sinus infection.

The distribution of radiographic changes among the varieties of uveitis is shown in Table VIII (overleaf); there was no significantly increased incidence in any variety. Of the 62 patients with radiographic changes, 37 were seen by the E.N.T. surgeon; the incidence of clinical sinus infection is shown in 
Table VIII. The incidence in those patients examined by the E.N.T. surgeon was higher in granulomatous anterior uveitis of unknown association ( 78 per cent.) than in the remainder of the series ( 36 per cent.); this difference was just significant $(P=0.04)$. The proportion of patients with radiographic changes who attended for clinical examination ( 60 per cent.) was unfortunately rather low, though it was the same for granulomatous anterior uveitis of unknown association as for the series as a whole.

TABLE VIII

SINUS CHANGES IN VARIETIES OF UVEITIS

\begin{tabular}{|c|c|c|c|c|c|c|c|c|}
\hline \multirow{2}{*}{\multicolumn{2}{|c|}{$\begin{array}{l}\text { Association with Local } \\
\text { or General Disease }\end{array}$}} & \multirow{3}{*}{$\begin{array}{c}\begin{array}{c}\text { Kerato- } \\
\text { uveitis }\end{array} \\
14 \\
6\end{array}$} & \multicolumn{3}{|c|}{ Anterior Uveitis } & \multirow{3}{*}{\begin{tabular}{|c|} 
Posterior \\
Uveitis
\end{tabular}} & \multirow{3}{*}{$\begin{array}{c}\text { Pan- } \\
\text { uveitis }\end{array}$} & \multirow{3}{*}{$\begin{array}{c}\text { Total } \\
51 \\
18\end{array}$} \\
\hline & & & \multirow{2}{*}{$\begin{array}{c}\begin{array}{c}\text { Granulo- } \\
\text { matous }\end{array} \\
4 \\
1\end{array}$} & \multirow{2}{*}{\begin{tabular}{|c}
$\begin{array}{c}\text { Non- } \\
\text { Granulo- } \\
\text { matous }\end{array}$ \\
$\begin{array}{r}25 \\
9\end{array}$
\end{tabular}} & \multirow{2}{*}{$\begin{array}{c}\text { Doubtful } \\
\text { Type }\end{array}$} & & & \\
\hline \multirow{2}{*}{$\begin{array}{l}\text { Known } \\
\text { Associa- } \\
\text { tion }\end{array}$} & $\begin{array}{l}\text { Radiographs Taken } \\
\text { No. Positive }\end{array}$ & & & & & & & \\
\hline & $\begin{array}{l}\text { E.N.T. Examination } \\
\text { Clinical Infection }\end{array}$ & $\begin{array}{l}4 \\
2\end{array}$ & - & $\begin{array}{l}4 \\
2\end{array}$ & $\begin{array}{l}1 \\
1\end{array}$ & - & 二 & $\begin{array}{l}9 \\
5\end{array}$ \\
\hline \multirow{2}{*}{$\begin{array}{l}\text { No } \\
\text { Known } \\
\text { Associa- } \\
\text { tion }\end{array}$} & $\begin{array}{l}\text { Radiographs Taken } \\
\text { No. Positive }\end{array}$ & $\begin{array}{r}16 \\
5\end{array}$ & $\begin{array}{l}43 \\
14\end{array}$ & $\begin{array}{l}54 \\
11\end{array}$ & $\begin{array}{r}17 \\
7\end{array}$ & $\begin{array}{r}27 \\
6\end{array}$ & $\begin{array}{l}3 \\
1\end{array}$ & $\begin{array}{r}160 \\
44\end{array}$ \\
\hline & $\begin{array}{l}\text { E.N.T. Examination } \\
\text { Clinical Infection }\end{array}$ & $\begin{array}{l}4 \\
1\end{array}$ & $\begin{array}{l}9 \\
7\end{array}$ & $\begin{array}{c}4 \\
-\end{array}$ & $\begin{array}{l}5 \\
2\end{array}$ & $\begin{array}{l}5 \\
2\end{array}$ & 1 & $\begin{array}{l}28 \\
12\end{array}$ \\
\hline
\end{tabular}

Eleven patients with granulomatous anterior uveitis of unknown association, aged over 50 years, had radiographic sinus changes; seven of them were examined clinically, six ( 86 per cent.) being found to have sinus infection. In the remaining varieties of uveitis, fourteen patients were in the same age group; nine were examined clinically, but only two (22 per cent.) showed sinus infection; the difference in percentage is significant $(P=0.02)$.

If we consider the patients who were fully investigated for sinus infection (i.e. were shown to be without radiographic changes, or, having such changes, were seen by the E.N.T. surgeon), the group with granulomatous anterior uveitis of unknown association contained 18 per cent. (seven of 38 patients) with clinical infection, compared with 7 per cent. (ten of 148 patients) in the remainder of the series; this difference is not quite significant by the $\chi^{2}$ test $\left(\chi^{2}=3.7 ; P=0.06\right)$, though this test is not very accurate with these small numbers. In females, five of 29 patients with granulomatous anterior uveitis of no known association had clinical sinus infection, compared with three of 72 patients in the remainder of the series; this difference is just significant $(P=0.04)$. In patients over 50 years of age, 33 per cent. (six of eighteen patients) with granulomatous anterior uveitis of no known association showed clinical infection, compared with 4 per cent. (two of 47 patients) in the remainder of the series; this difference is highly significant $(P=0.005)$; 
only four females in this age group had clinical sinus infection, and all had granulomatous anterior uveitis.

The very chronic type of granulomatous anterior uveitis of unknown association is compared with the less chronic type in Table IX.

There is a tendency, not statistically significant, for the very chronic type to be associated with a greater proportion of positive radiographs and of clinical sinus infection.

TABLE IX

NASAL SINUS INFECTION IN GRANULOMATOUS ANTERIOR UVEITIS OF UNKNOWN ASSOCIATION

\begin{tabular}{|c|c|c|c|c|c|c|c|}
\hline \multirow{2}{*}{\multicolumn{2}{|c|}{ Age Group (yrs) }} & \multicolumn{2}{|c|}{ Chronic Type } & \multicolumn{2}{|c|}{ Less Chronic Type } & \multicolumn{2}{|c|}{ Total } \\
\hline & & Male & Female & Male & Female & Male & Female \\
\hline \multirow{3}{*}{ All Ages } & No. of Patients & 4 & 22 & 7 & 13 & 11 & 35 \\
\hline & $\begin{array}{l}\text { Radiographs Taken ... } \\
\text { No. Positive }\end{array}$ & $\begin{array}{l}4 \\
2\end{array}$ & $\begin{array}{r}21 \\
9\end{array}$ & $\begin{array}{l}7 \\
2\end{array}$ & $\begin{array}{r}11 \\
1\end{array}$ & $\begin{array}{r}11 \\
4\end{array}$ & $\begin{array}{l}32 \\
10\end{array}$ \\
\hline & $\begin{array}{l}\text { E.N.T. Examination... } \\
\text { Clinical Infection ... }\end{array}$ & 2 & $\begin{array}{l}6 \\
4\end{array}$ & 二 & $\begin{array}{l}1 \\
1\end{array}$ & $\begin{array}{l}2 \\
2\end{array}$ & $\begin{array}{l}7 \\
5\end{array}$ \\
\hline \multirow{3}{*}{$>50$} & No. of Patients & 2 & 12 & 4 & 7 & 6 & 19 \\
\hline & $\begin{array}{c}\text { Radiographs Taken } \\
\text { No. Positive }\end{array}$ & $\begin{array}{l}2 \\
2\end{array}$ & $\begin{array}{r}11 \\
6\end{array}$ & $\begin{array}{l}4 \\
2\end{array}$ & $\begin{array}{l}5 \\
1\end{array}$ & $\begin{array}{l}6 \\
4\end{array}$ & $\begin{array}{r}16 \\
7\end{array}$ \\
\hline & $\begin{array}{l}\text { E.N.T. Examination ... } \\
\text { Clinical Infection ... }\end{array}$ & $\begin{array}{l}2 \\
2\end{array}$ & $\begin{array}{l}4 \\
2\end{array}$ & 二 & 1 & 2 & $\begin{array}{l}5 \\
4\end{array}$ \\
\hline
\end{tabular}

The increased incidence of clinical sinus infection in granulomatous anterior uveitis in patients over the age of 50 years is complementary to the increased incidence of dental infection already found in the age group 2140 years. In patients of all ages who were investigated fully for both dental and sinus infections, 50 per cent. (eighteen of 36 patients) of cases of this variety of uveitis showed one or both infections, compared with 27 per cent. (38 of 140 patients) of the remainder of the series; this difference is significant $\left(\chi^{2}=6.0 ; P<0.02\right)$.

Throat Cultures.-The organisms of greatest interest are those which are not normally found in the upper respiratory tract, particularly Streptococcus haemolyticus. Streptococcus viridans is a normal finding in throat cultures, and was only noted when it was obviously the preponderating organism present. The other organisms noted were pneumococcus, Streptococcus faecalis, non-haemolytic streptococcus, and Haemophilus influenzae and para-influenzae.

The incidence of positive direct throat cultures is shown in Table $\mathrm{X}$ (overleaf); there was an increased incidence of Streptococcus haemolyticus in the group of uveitis with no known association, especially in anterior uveitis, but this was not statistically significant. 
TABLE X

ROUTINE THROAT CULTURES

\begin{tabular}{|c|c|c|c|c|c|c|c|c|}
\hline & & & An & terior Uv & eitis & & & \\
\hline $\begin{array}{l}\text { Asso } \\
\text { or }\end{array}$ & $\begin{array}{l}\text { ciation with Local } \\
\text { General Disease }\end{array}$ & $\begin{array}{l}\text { Kerato- } \\
\text { uveitis }\end{array}$ & Granulo- & \begin{tabular}{|c} 
Non- \\
Granulo-
\end{tabular} & Doubtful & $\begin{array}{c}\text { Posterior } \\
\text { Uveitis }\end{array}$ & $\begin{array}{l}\text { Pan- } \\
\text { uveitis }\end{array}$ & Total \\
\hline & Cultures Taken & 12 & 5 & 24 & 6 & - & - & 47 \\
\hline $\begin{array}{l}\text { Associa- } \\
\text { tion }\end{array}$ & $\begin{array}{l}\text { Strep. haemolyticus } \\
\text { Strep. viridans } \\
\text { Others } \quad \ldots\end{array}$ & $\underline{2}$ & $\begin{array}{l}\overline{1} \\
1\end{array}$ & $\begin{array}{l}2 \\
3 \\
1\end{array}$ & $\begin{array}{l}\overline{2} \\
1\end{array}$ & E & 三 & $\begin{array}{l}2 \\
8 \\
3\end{array}$ \\
\hline & Cultures Taken & 16 & 45 & 59 & 16 & 26 & 3 & 165 \\
\hline $\begin{array}{c}\text { Known } \\
\text { Associa- } \\
\text { tion }\end{array}$ & $\begin{array}{l}\text { Strep. haemolyticus } \\
\text { Strep. viridans } \\
\text { Others } \quad \ldots\end{array}$ & $\begin{array}{l}3 \\
4 \\
3\end{array}$ & $\begin{array}{r}9 \\
12 \\
5\end{array}$ & $\begin{array}{r}11 \\
11 \\
5\end{array}$ & $\begin{array}{r}1 \\
3 \\
-\end{array}$ & $\begin{array}{l}3 . \\
10 \\
-\end{array}$ & $\underline{-}$ & $\begin{array}{l}27 \\
41 \\
13\end{array}$ \\
\hline
\end{tabular}

Pathogen selective cultures were taken from 184 patients; only 21 failed to grow Streptococcus viridans, and only nine of these failed to grow either Streptococcus haemolyticus or one of the other organisms listed above, and the cultures from patients with known association with local or general disease did not behave differently from the remainder of the series. Of the 42 pathogen selective cultures from patients with Streptococcus viridans predominating in their direct throat cultures, 36 grew this organism, including five of the six from patients with known association with local or general disease; fifteen of the 28 pathogen selective cultures from patients with Streptococcus haemolyticus in the direct throat cultures grew this organism, including the cultures from each of the two patients with a known association with local or general disease, one having secondary syphilis and one typical ankylosing spondylitis. It is obvious, therefore, that the pathogen selective test does not predict which organisms are related to the uveitis.

Streptococcus haemolyticus was grown in the pathogen selective cultures of four patients in whom direct throat cultures had failed to reveal it, two having non-granulomatous anterior uveitis, one granulomatous anterior uveitis, and one posterior uveitis, all without known association with local or general disease. Dr. F. B. Jackson (personal communication), who carried out these cultures, considers that " these were certainly not due to contamination, or to a bacteriaemia, but were probably present in the secretion from the patients, being overgrown by the normal upper respiratory tract flora (in spite of the use of selective media), but growing when large proportions of the normal flora were inhibited, as appeared to be the case when cultures from the throat were incubated in the presence of the patient's blood ". The method may therefore possibly be of help in isolating Streptococcus haemolyticus; the almost universal presence of Streptococcus viridans in the 
pathogen selective culture indicates that the latter is of no value as far as this organism is concerned.

Nasal Cultures.-These were taken from 207 patients; only two showed Streptococcus haemolyticus, both being from patients with anterior uveitis of no known association, one granulomatous and one non-granulomatous; the latter also had Streptococcus haemolyticus in the throat culture. There was no suggestion of a significant incidence of Streptococcus viridans infection.

\section{Combined Nose and Throat Cultures}

Streptococcus haemolyticus.-The incidence of Streptococcus haemolyticus in those patients who have had all three investigations performed (nasal, direct throat, and pathogen selective cultures) is shown in Table XI.

The incidence of positive cultures in patients with rheumatic disease was low; seventeen patients who were aware of their rheumatic disease had all the cultures performed, none being positive for Streptococcus haemolyticus; if these patients were eliminated, the increased incidence of positive cultures in uveitis of no known association is not significant. In these patients, the incidence in those with previous attacks of uveitis (seven in 38 patients) was almost the same as in those without previous attacks (26 in 124 patients).

TABLE XI

COMBINED NOSE AND THROAT CULTURE

\begin{tabular}{|c|c|c|c|c|c|c|c|c|c|c|c|}
\hline \multirow{2}{*}{\multicolumn{3}{|c|}{$\begin{array}{l}\text { Association with Local } \\
\text { or General Disease }\end{array}$}} & \multicolumn{3}{|c|}{ Male } & \multicolumn{3}{|c|}{ Female } & \multicolumn{3}{|c|}{ Total } \\
\hline & & & 4 党 & $\frac{5}{0}$ & 효 & $4 \stackrel{0}{0}$ & $\begin{array}{c}3 \\
.0 \\
0 \\
0 \\
0\end{array}$ & 宝 & $\leftarrow \stackrel{0}{0}$ & $\frac{5}{0} \cdot \frac{0}{0}$ & 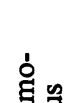 \\
\hline \multirow{2}{*}{$\begin{array}{l}\text { Known } \\
\text { Associa- } \\
\text { tion }\end{array}$} & $\begin{array}{l}\text { Non-rheumatic } \\
\text { Rheumatic }\end{array}$ & $\begin{array}{l}\cdots \\
\cdots\end{array}$ & $\begin{array}{r}7 \\
21\end{array}$ & $\begin{array}{l}1 \\
1\end{array}$ & 1 & $\begin{array}{l}5 \\
5\end{array}$ & - & $\begin{array}{l}1 \\
1\end{array}$ & $\begin{array}{l}12 \\
26\end{array}$ & $\begin{array}{l}1 \\
1\end{array}$ & $\begin{array}{l}2 \\
1\end{array}$ \\
\hline & Total $\ldots$ & $\ldots$ & 28 & 2 & 1 & 10 & - & 2 & 38 & 2 & 3 \\
\hline \multicolumn{2}{|c|}{ No Known Association } & $\ldots$ & 63 & 9 & 9 & 78 & 22 & 9 & 141. & 31 & 18 \\
\hline Total & $\ldots$ & $\ldots$ & 91 & 11 & 10 & 88 & 22 & 11 & 179 & 33 & 21 \\
\hline
\end{tabular}

The distribution of positive cultures in the varieties of uveitis is shown in Table XII (overleaf), which does not include patients with rheumatic disease of which they were aware. The increased incidence in the patients with no known association with local or general disease occurred mainly in those with anterior uveitis, but the difference between this group and the remainder of the series was not statistically significant.

In patients aged over 40 years, there was an increased incidence in patients with anterior uveitis without known association with local or general disease 
(twenty positive cultures in seventy patients) compared with the remainder of the series (two in 29 patients); this difference is significant $\left(\chi^{2}=4 \cdot 4, P=0.04\right)$. In the age group 41-50 years, the incidence in granulomatous anterior uveitis (57 per cent.) was greater than in the remainder of the anterior uveitis group ( 36 per cent.), and this was even more marked in patients aged over 50 years (30 and 6 per cent. respectively). In the latter age group, the incidence in granulomatous anterior uveitis (six in twenty patients) was significantly higher $(P<0.01)$ than in the remainder of the series (one in 33 patients); the increased incidence appeared to be independent of sex. The incidence of positive cultures in granulomatous anterior uveitis was greater in the chronic type (38 per cent.) than in the less chronic type (18 per cent.). The proportion of positive cultures in granulomatous anterior uveitis was consistently high throughout the year, so the association was not due to a tendency for patients with this type of uveitis to attend at a time when Streptococcus haemolyticus was common.

The association of Streptococcus haemolyticus with granulomatous anterior uveitis becomes clearer if one considers the relationship of positive cultures to clinical sepsis in the teeth and nasal sinuses. It is not unreasonable to assume that patients with such sepsis may have a greater tendency to harbour streptococci in nose and throat, and that this may bear little relationship to uveitis in those patients. In patients who were fully investigated both for sepsis and for Streptococcus haemolyticus, the total incidence of positive cultures in patients with parodontal or sinus sepsis (eleven in 42 patients) was indeed higher than that in patients without sepsis (eighteen in ninety patients), and it did not show any tendency to be greater in patients with anterior uveitis of no known association; in patients without sepsis, howere the incidence was obviously much higher (seven in fourteen patients) in patients with granulomatous anterior uveitis than in the remainder of the series (eleven in 76 patients); the $\chi^{2}$ test shows this to be significant $\left(\chi^{2}=7 \cdot 3\right.$; $P<0.01$ ), though with these relatively small numbers the level of significance is not given accurately. In females without clinical sepsis, six of eleven patients with granulomatous anterior uveitis of no known association had positive cultures, compared with eight of forty in the remainder of the series; this difference is significant $(P=0 \cdot 03)$.

In all cases, the organism was tested to see whether or not it belonged to Lancefield groups A, B, C, D, or G. In granulomatous anterior uveitis, a Group-A streptococcus was found in only one patient, who had a strongly positive gonococcal complement-fixation test and radiological evidence of active chest tuberculosis; a Group- $\mathrm{C}$ streptococcus was found in one patient, and a streptococcus belonging to none of the above groups in the remaining nine patients. In the remainder of the series, the organism belonged to Group A in three patients, to Groups B, C, and D in one patient each, to Group $G$ in four patients, and to none of the above groups in thirteen patients. 
Streptococcus viridans.-It has already been pointed out that the almost universal presence of Streptococcus viridans in the pathogen selective cultures makes this test useless for this organism. In those patients who had both nasal and direct throat cultures performed, there was no evidence of increased incidence in any type of uveitis in any age group.

Pneumococci.-These were cultured from 23 patients, 21 of whom had had all three cultures performed (Table XI). In the series as a whole, there was no significantly increased incidence in any variety of uveitis (Table XII), but in patients aged less than 41 years, there was a higher incidence in those with anterior uveitis of no known association (nine in 32 patients) than in the remainder of the age group (one in 31 patients); the difference was statistically significant $(P<0.01)$. In this age group, both males and females showed a high incidence; there was no evidence that seasonal factors played a part.

TABLE XII

NOSE AND THROAT CULTURES: VARIETIES OF UVEITIS

\begin{tabular}{|c|c|c|c|c|c|c|c|c|}
\hline & & & & terior Uve & eitis & & & \\
\hline $\begin{array}{l}\text { Asso } \\
\text { or }\end{array}$ & $\begin{array}{l}\text { iation with Local } \\
\text { ieneral Disease** }\end{array}$ & $\begin{array}{l}\text { Kerato- } \\
\text { uveitis }\end{array}$ & Granulo- & Granulo- & Doubtful & $\begin{array}{c}\text { Posterior } \\
\text { Uveitis }\end{array}$ & $\begin{array}{l}\text { Pan- } \\
\text { uveitis }\end{array}$ & Total \\
\hline $\begin{array}{l}\text { Known } \\
\text { Associa- } \\
\text { tion }\end{array}$ & $\begin{array}{l}\text { No. of patients } \ldots \\
\text { Strep. haemolyticus } \\
\text { Pneumococcus } \quad \ldots\end{array}$ & $\frac{7}{-}$ & $\frac{3}{1}$ & $\begin{array}{l}9 \\
2 \\
1\end{array}$ & $\frac{2}{1}$ & E. & 三 & $\begin{array}{r}21 \\
2 \\
3\end{array}$ \\
\hline $\begin{array}{c}\text { No } \\
\text { Known } \\
\text { Associa- } \\
\text { tion }\end{array}$ & $\begin{array}{l}\text { No. of Patients } \ldots \\
\text { Strep. haemolyticus } \\
\text { Pneumococcus _.. }\end{array}$ & $\begin{array}{r}15 \\
3 \\
2\end{array}$ & $\begin{array}{r}38 \\
11 \\
7\end{array}$ & $\begin{array}{r}50 \\
13 \\
8\end{array}$ & $\begin{array}{r}14 \\
1 \\
1\end{array}$ & $\begin{array}{r}22 \\
3 \\
-\end{array}$ & $\underline{2}$ & $\begin{array}{r}141 \\
31 \\
18\end{array}$ \\
\hline
\end{tabular}

* Patients aware of their rheumatic disease are excluded

In patients who had been fully investigated for dental and sinus sepsis and for pneumococcal infection, the total incidence of positive cultures was almost the same in those with sepsis as in those without; in both groups it was higher in those with anterior uveitis of no known association than in the remainder, but in neither group was the difference statistically significant. In patients under the age of 41 years without clinical parodontal or nasal sinus sepsis, six of the fourteen patients with anterior uveitis of no known association had positive cultures, compared with none of the fifteen patients in the remainder of the series; this difference is significant $(P<0.01)$. Positive cultures were found in both the patients with uveitis of granulomatous type and in three of the eight patients with uveitis of non-granulomatous type.

Seven patients with granulomatous anterior uveitis of no known association, only two of whom were aged less than 41 years, were found to be free from parodontal, sinus, and Streptococcus haemolyticus infections after full 
investigation; three of them had pneumococcal infection; this incidence is just significant $(P=0.048)$ when compared with that in all patients who were fully investigated (excluding those who were aware of their rheumatic disease). This suggests that the association of pneumococcal infection with anterior uveitis was primarily with the granulomatous type. There were, however, seven more patients with granulomatous anterior uveitis who had full investigation of their nose and throat cultures, but who did not have either their teeth or sinuses fully examined; none of these patients had pneumococci in their cultures, and although only one of these patients was under 40 years of age, this throws some doubt on the possibility that there is a particular association between pneumococci and granulomatous anterior uveitis.

Other Organisms.-Streptococcus faecalis was cultured in four patients, and non-haemolytic streptococci in three; in each case, one patient had uveitis associated with rheumatic disease, so that there was no evidence of a significant association of these organisms with uveitis. Haemophilus influenzae or para-influenzae was cultured in seven patients; two had keratouveitis, one granulomatous anterior uveitis, two non-granulomatous anterior uveitis, and two anterior uveitis of a doubtful type, all with no known association with local or general disease. Bacillus proteus was cultured in one patient with granulomatous anterior uveitis of no known association.

Other Infections.-Particular interest centres in those patients with granulomatous anterior uveitis who did not show sepsis in teeth or sinuses or infection with Streptococcus haemolyticus.

There were seven such patients among those who were fully investigated for infection.

Three of these had pneumococcal infection, one also having chronic generalized gingivitis (which had not been considered sufficient to justify a diagnosis of parodontal infection) together with some bone absorption around $7 \mid$; he also gave a history of in-patient treatment for maxillary sinusitis in 1951.

One patient showed Bacillus proteus in the throat.

Two other patients had no evidence whatsoever of infection.

The seventh patient (Case 1), a female aged 41 years, had chronic asthma and eczema; the urine showed albumin, pus, and red blood cells, and the gonococcal complementfixation test, carried out on three occasions, was positive once and doubtful twice. The venereologist thought it was extremely doubtful if the aetiology were gonococcal. The full blood count was borderline, showing 11,000 white cells ( 71 per cent. polymorphs); a second count showed 10,800 white cells (67 per cent. polymorphs). Rheumatological examination was negative, but radiographs were not taken.

In addition to this patient, genito-urinary infection was proved in two others (Cases 2 and 3) with granulomatous anterior uveitis.

Case 2, a female aged 48 years, had leucorrhoea, probably due to Trichomonas vaginalis, and chronic cervicitis; a catheter specimen of urine showed pus and red blood cells, but culture was sterile; throat swab showed haemolytic streptococci and $B$. coli, and swabs from an ulcerated nipple showed pneumococci. 
Case 3, a female aged 76 years, had cystitis due to infection with Bacillus coli.

On the other hand, one patient with uveitis associated with dendritic corneal ulceration also had cystitis due to Bacillus coli infection, and one patient (Case 13) with anterior uveitis of doubtful type had albuminuria, diabetes, and uraemia, from which he died; no post mortem examination was carried out.

Four other patients, none of whom had granulomatous anterior uveitis, had albuminuria on their first examination, but a second examination in three of them was normal; the fourth did not attend for further examination. It may be, therefore, that the association of granulomatous anterior uveitis with genito-urinary infection in the cases described above was coincidental.

One of the patients with genito-urinary infection and granulomatous uveitis (Case 3) also had radiographic evidence of marked bronchitic changes in both lung fields; in addition, one patient with kerato-uveitis had radiographic and clinical evidence of bronchiectasis. One patient with non-granulomatous anterior uveitis and definite ankylosing spondylitis gave a history of pneumonia 3 weeks before the onset of uveitis, but this was shown to be associated with a bronchogenic carcinoma. A history of recent bronchitis or influenza was given by five other patients, two having non-granulomatous anterior uveitis, one anterior uveitis of doubtful type, one posterior uveitis, and one kerato-uveitis; in all cases there were no recent radiographic lung changes. Four patients had chronic bronchitis without radiographic changes; one had granulomatous anterior uveitis associated with nasal sinus and Streptococcus haemolyticus infections, one had posterior uveitis, and two had non-granulomatous anterior uveitis, including one with ankylosing spondylitis. There is, therefore, no evidence of a special relationship between influenza or bronchitis and any particular type of uveitis.

One patient with posterior uveitis gave a history of recent tonsillitis, but cultures showed no significant organisms; and one patient had kerato-uveitis and chronic osteomyelitis of the elbow with a discharging sinus due to a war injury.

A full blood count was performed on 208 patients; the upper limit of white cells was taken to be 11,000 , with up to 70 per cent. polymorphs (or up to 7,500 polymorphs per cu. mm.). On this basis, 21 patients had polymorpho-leucocytosis; of these, eighteen had one or more infections of the teeth, nasal sinuses, or throat, one had radiographic neoplastic changes in the pelvis and spine, one was pregnant, and one had typical ankylosing spondylitis and had not been examined by the dental surgeon.

There was, therefore, no definite evidence of significant infections other than those in the teeth and upper respiratory tract.

\section{INCIDENCE OF SIGNIFICANT FOCAL INFECTION}

In patients who have had a full investigation for parodontal, nasal sinus, and Streptococcus haemolyticus infections, excluding those with rheumatic disease of which they were aware, 23 (77 per cent.) of the thirty patients with granulomatous anterior uveitis of otherwise unknown association had proved infection, compared with 37 (36 per cent.) of the remaining 102 patients in the series; this difference is highly significant $\left(\chi^{2}=13.5 ; P<0.001\right)$.

Included in these thirty patients with granulomatous anterior uveitis were 26 
two with heterochromic cyclitis and one with the Vogt-Koyanagi syndrome, all of whom had one of the forms of infection. If it is assumed that these diseases were not associated with infection except by chance, twenty of the remaining 27 patients had infection, compared with forty of the 105 patients in the remainder of the series; the difference is still highly significant $\left(\chi^{2}=9 \cdot 8\right.$; $P=0.01)$. Infection was found in only three of the 23 patients in the remainder of the series who had had previous attacks; even when these patients are excluded, the increased incidence in granulomatous anterior uveitis was still significant $\left(\chi^{2}=5 \cdot 7 ; P=0 \cdot 02\right)$.

Eighteen of the 26 patients with granulomatous anterior uveitis of the very chronic type had proved infection, including fifteen of the seventeen who were fully investigated for these infections. Alternatively the patients with granulomatous anterior uveitis may be subdivided into those in whom pan-uveitis could or could not be excluded; of the latter, sixteen of seventeen patients who were fully investigated had proved infection, compared with seven of thirteen in whom pan-uveitis could be excluded. Both the patients with pan-uveitis who had been fully investigated had proved infection.

Patients with granulomatous anterior uveitis or pan-uveitis and parodontal, nasal sinus, or Streptococcus haemolyticus infection will therefore be considered as a separate group in which uveitis was "associated with infection". This comprised one patient with sarcoidosis and 28 patients with uveitis of hitherto unknown association, including two patients with heterochromic cyclitis, one with the Vogt-Koyanagi syndrome, one with probably active chest tubercle, and one with inadequately treated congenital syphilis. Since parodontal, sinus, and haemolytic streptococcal infections are relatively common, it must be expected that the association in some of these patients was due to coincidence.

The importance of the association of anterior uveitis with pneumococcal infection in the nose and throat is more difficult to evaluate. It was not certain that the association was with the granulomatous type of anterior uveitis, and it was apparently confined, for no very obvious reason, to patients under the age of 41 years.

\section{Focal InFECTION AS a CAUSE OF UveItis}

The finding of an association of uveitis with infection does not in itself, of course, necessarily indicate that the connexion is a causal one. It may well be that patients with granulomatous uveitis due to some unknown cause are also liable to infections. If this were the case, it might be expected that the same type of uveitis might show an increased tendency to be associated with other infections; this was not found to be the case, except possibly for infection with the pneumococcus, which can in any case be considered to be a form of streptococcus.

If the infection is of causal significance, it would be expected that treat- 
ment of the infection would lead to an improvement in the prognosis for the ocular disease. This was not found to be the case by Guyton and Woods (1941); they were, however, studying mainly the incidence of recurrences in non-granulomatous uveitis. In the present series it was not considered justifiable, in the present state of our knowledge, to withhold treatment for any septic process discovered in the teeth or sinuses, and the only patients who did not receive such treatment were therefore those who defaulted. No attempt was made, however, to eliminate Streptococcus haemolyticus from the nose or throat, so a comparison may be made (Table XIII) between those in whom the infection (i.e. parodontal or sinus infection) was adequately treated, and those in whom the infection (i.e. Streptococcus haemolyticus infection with or without parodontal or sinus infection) was untreated or incompletely treated. The criterion of resolution of the uveitis was the cessation of all treatment with mydriatics. The period of follow-up varied from 1 to $3 \frac{1}{2}$ years (average $2 \frac{1}{2}$ years) and was the same for the two groups. Table XIII shows that the prognosis for patients with infection was better for those adequately treated; treatment of parodontal or sinus infection in those patients in whom Streptococcus haemolyticus was also found gave no better prognosis than in those patients with streptococci alone. The prognosis was intermediate in those patients in whom no infection was found. These findings were consistent with an association between adequate treatment of the infection and an improvement in the ocular prognosis, but they may also be interpreted as indicating merely that uveitis associated with Streptococcus haemolyticus infection had inherently a worse prognosis than uveitis associated with parodontal or sinus infection.

TABLE XIII

GRANULOMATOUS ANTERIOR UVEITIS AND PAN-UVEITIS: RESPONSE TO TREATMENT OF INFECTION

\begin{tabular}{|c|c|c|c|c|c|c|c|c|}
\hline \multirow{2}{*}{$\begin{array}{r}\text { Type of } \\
\text { Patient }\end{array}$} & \multirow[b]{2}{*}{ Treatment of Infection } & \multirow{2}{*}{$\begin{array}{l}\text { Total } \\
\text { Fol- } \\
\text { lowed- } \\
\text { up }\end{array}$} & \multicolumn{2}{|c|}{ Resolved in } & \multirow{2}{*}{$\begin{array}{l}\text { Still } \\
\text { under } \\
\text { Treat- } \\
\text { ment }\end{array}$} & \multirow{2}{*}{$\begin{array}{l}\text { Recur- } \\
\text { rence } \\
\text { after } \\
\text { Reso- } \\
\text { lution }\end{array}$} & \multicolumn{2}{|c|}{$\begin{array}{l}\text { Unsatis- } \\
\text { factory } \\
\text { Response }\end{array}$} \\
\hline & & & \begin{tabular}{|c|}
6 \\
Months \\
or Less
\end{tabular} & $\begin{array}{c}\text { More } \\
\text { than } \\
6 \\
\text { Months }\end{array}$ & & & Total & $\begin{array}{l}\text { Per- } \\
\text { cent- } \\
\text { age }\end{array}$ \\
\hline \multirow[b]{2}{*}{ All Patients } & No Infection Found ... & 18 & 13 & 1 & 4 & 3 & 7 & 39 \\
\hline & $\begin{array}{l}\text { Adequately Treated ... } \\
\text { Not adequately Treated }\end{array}$ & $\begin{array}{l}14 \\
10\end{array}$ & $\begin{array}{l}9 \\
5\end{array}$ & $\begin{array}{l}2 \\
2\end{array}$ & $\begin{array}{l}3 \\
3\end{array}$ & $\overline{3}$ & $\begin{array}{l}3 \\
6\end{array}$ & $\begin{array}{l}21 \\
60\end{array}$ \\
\hline \multirow{2}{*}{$\begin{array}{l}\text { No. fully } \\
\text { Investigated } \\
\text { for Infection }\end{array}$} & No Infection Found ... & 7 & 5 & 1 & 1 & 1 & 2 & 29 \\
\hline & $\begin{array}{l}\text { Adequately Treated } \ldots \\
\text { Not adequately Treated }\end{array}$ & $\begin{array}{l}11 \\
10\end{array}$ & $\begin{array}{l}7 \\
5\end{array}$ & $\begin{array}{l}2 \\
2\end{array}$ & $\begin{array}{l}2 \\
3\end{array}$ & $\overline{3}$ & $\begin{array}{l}2 \\
6\end{array}$ & $\begin{array}{l}18 \\
60\end{array}$ \\
\hline
\end{tabular}

If sepsis were the sole cause of the uveitis in these patients, it would be expected that adequate treatment would, in all cases, lead to a resolution 
of the ocular inflammation; the histories of the three patients (Cases 4, 5, and 6) who had an unsatisfactory response are therefore of interest; all had granulomatous anterior uveitis in which pan-uveitis could not be excluded, and in two (Cases 4 and 6) the uveitis was of the very chronic type.

Case 4, a male aged 35 years, had been treated elsewhere for 5 weeks; his visual acuity when first seen was hand movements only. The only significant finding on investigation was a discharging parodontal abscess, which was treated by removal of carious teeth. In spite of local treatment, combined at various times with systemic cortisone and protein shock therapy, the eye, though much less actively inflamed, was still under treatment 18 months later at the time of the follow-up survey, but 3 months after this treatment was discontinued, the eye being quiet and without keratic precipitates, but soft and becoming divergent.

Case 5, a female aged 43 years, had had treatment intermittently elsewhere for 16 months, and when first seen had secondary glaucoma, for which a trephine operation was performed. The only significant finding on investigation was parodontal disease of the lower anteriors, with radiological evidence of loss of alveolar bone. She was still under treatment 12 months later at the time of the follow-up survey, but the keratic precipitates, dilated iris vessels, and vascular exudate in the pupillary area were slowly subsiding; local treatment was discontinued 3 months later, and the patient is being fitted with a cosmetic contact lens.

Case 6, a female aged 59 years, had had bilateral iridectomy elsewhere for chronic cyclitis 9 months previously, and the inflammation had become active again 2 months before she attended the University Department; the visual acuity was less than $6 / 60$. The only significant findings on investigation were chronic parodontal and nasal sinus infections, which were successfully treated by dental extractions and antral lavage; a nasal culture had not been taken. In spite of local treatment and protein shock therapy, the cyclitis still showed periodic evidence of activity at the time of the follow-up survey 18 months later; a nasal culture, taken to complete the full investigation for sepsis, showed Staphylococcus pyogenes only.

In the first two of these patients, the initial iridocyclitis was of considerable severity, but the subsequent history was consistent with a steady improvement after the removal of the infections in the teeth and sinuses, the poor final result being due to the damage inflicted by the initial attack. The third patient, however, retains an active cyclitis in spite of removal of the infections, which are presumably, therefore, coincidental.

In view of the relatively better prognosis in patients who were adequately treated, the response to antibiotic treatment in patients with Streptococcus haemolyticus infection would be of considerable interest. In the three such patients who had had a recurrence of uveitis after cessation of ocular treatment, the effect of elimination of the streptococcal infection in preventing recurrences could only be assessed over a long period, and cannot be usefully discussed further at present. Of the three patients still under treatment at the time of the follow-up survey, one had a shrunken eye following operations for secondary glaucoma and a swollen lens, and the uveitis in one patient subsided 3 months later so that mydriasis could be discontinued; the third (Case 7) was the only patient in whom antibiotic treatment appeared to be worthwhile. 
Case 7, a female aged 64 years, had bilateral anterior uveitis in which pan-uveitis could not be excluded; she was highly myopic with central degenerative changes. The only significant finding on investigation was Streptococcus haemolyticus in the throat cultures. She developed secondary glaucoma in one eye, but this was controlled with Diamox. In September, 1956. Streptococcus haemolyticus was still present in the throat swab but was eliminated by systemic penicillin therapy; there was subsequently a diminution in the number of keratic precipitates, which were becoming pigmented, and slit-lamp examination showed only a very faint aqueous flare. Diamox was discontinued in November, 1956 , and there had been no rise in ocular tension one month later.

It is obviously not possible to draw firm conclusions from these patients, but the findings are at any'rate not inconsistent with the supposition that in many patients granulomatous anterior uveitis and pan-uveitis are caused by the associated infection; elimination of such infections would appear to be well worth further trial in these types of uveitis.

\section{SYSTEMIC DISEASES}

\section{BY \\ A. STANWORTH}

Those patients in whom uveitis was considered to be associated with local or general disease have already been described. In a number of other patients, less definite associations were found.

\section{VeNEREAL DisEASES}

In two patients, syphilis was suspected to be a possible cause of uveitis.

Case 8, a male aged 68 years, with non-granulomatous anterior uveitis, had a positive Wassermann reaction and Kahn test, but he also had untreated diabetes mellitus and pneumococcal throat infection, and the syphilis may have been coincidental.

Case 9, a female aged 32 years, with recurrent granulomatous anterior uveitis, had congenital syphilis; she had been found elsewhere in 1948 to have a positive Kahn test but a negative Wassermann reaction, and had been treated with penicillin injections but had defaulted; in 1954 the Kahn test was positive but unstable, and again she defaulted after four injections; she had parodontal infection, and evidence of old tuberculous apical lung infection.

A history of treated syphilis leading to a negative Wassermann reaction was given by three patients, one with typical ankylosing spondylitis, one with Reiter's disease with radiographic evidence of spinal arthritis, and one with Reiter's disease without radiographic spinal changes.

The gonococcal complement-fixation test was performed on serum from 205 patients, and was found to be positive or strongly positive in seven. Two of these had uveitis ascribed to syphilis, and two had spondylitis. The remaining three patients all had anterior uveitis. 
Case 10, a male aged 52 years, with granulomatous anterior uveitis, had a strongly positive gonococcal complement-fixation test, Streptococcus haemolyticus in the throat cultures, and radiological evidence of active chest tuberculosis; he refused further investigation and treatment.

Case 11, a female aged 70 years, with bilateral granulomatous anterior uveitis, had a strongly positive gonococcal complement-fixation test, which, on repetition, was only doubtfully positive; the venereologist thought the condition was unlikely to be gonococcal.

Case 12, a female aged 42 years, with non-granulomatous anterior uveitis, was also seen by the venereologist, who considered that she could have had chronic gonococcal infection, but that there was no definite evidence.

In 25 patients the gonococcal complement-fixation test gave a doubtful result; it was repeated in seventeen patients, and was then found to be negative in eleven, still doubtful in five, and positive in one. It was considered by the venereologist that the positive reaction was unlikely to be due to gonococcal infection in the last patient, who has already been described (Case 1). In four patients (Cases 8, 9, 10, and 12), therefore, the uveitis may have been of venereal origin.

\section{DIABETES}

Seven patients had diabetes; two had had treatment, one by diet only, but neither was fully controlled. One patient with syphilis (Case 8) has already been described; one (Case 13), who had anterior uveitis of doubtful type, also suffered from albuminuria and uraemia from which he died, but no post-mortem examination was carried out; one had uveitis associated with superficial punctate keratitis and Streptococcus haemolyticus infection in the throat. The remaining four patients had anterior uveitis, one granulomatous and three of doubtful type; all cultures were negative in two, nasal sinus infection was absent in three, and parodontal infection was absent in three. There was therefore no evidence that uveitis had been produced in these patients by any greater liability to septic infections.

Three of the patients were more than 70 years of age, two were between 61 and 70 years (Cases 8 and 13), and two were between 41 and 50 years. The diabetes was therefore likely to be largely of the senile type, and may well have been coincidental in the majority of patients.

\section{TUBERCULOSIS AND SARCOIDOSIS}

Radiography of the chest was performed in 202 patients, and the Mantoux reaction to $0.1 \mathrm{mg}$. and to $0.01 \mathrm{mg}$. of human old tuberculin in 211 patients, the diameter of the reaction of oedema being recorded as + (less than $10 \mathrm{~mm}$.), $++(10-19 \mathrm{~mm}$.), or $+++(20 \mathrm{~mm}$. or more $)$.

Definite sarcoidosis was diagnosed in two females with granulomatous anterior uveitis; the Mantoux reaction was negative in one, and + to $0.1 \mathrm{mg}$. in the other, in whom it had been reported as negative 2 months previously. In two.others the clinical picture raised the possibility of sarcoidosis. 
Case 14, a female aged 26 years, with anterior uveitis of doubtful type and secondary glaucoma resembling the Posner-Schlossman syndrome, had radiographic enlargement of the hilar and right paratracheal lymph glands which could have been due to sarcoid or one of the reticuloses; the Mantoux reaction was negative; radiography of the hands and feet was negative, and the serum proteins were normal.

Case 15, a female aged 66 years, with granulomatous anterior uveitis, had an unexplained loss of weight of up to 3 stones at the time she had uveitis; a radiograph of the chest was reported to show "fine modulation in the lung fields; this is not quite definite but raises the possibility of sarcoidosis". A further radiograph one month later showed no abnormality, and the Mantoux reaction was positive $(+++$ to $0.01 \mathrm{mg}$.), so that a diagnosis of sarcoidosis was unlikely.

Possibly active tuberculous lesions were found in three patients. One (Case 10) had a strongly positive gonococcal complement-fixation test; the others are described below.

Case 16, a female aged 41 years, with bilateral anterior uveitis of doubtful type with secondary glaucoma, had radiographic evidence of old tuberculous chest lesions in which activity could not be excluded, but the patient defaulted.

Case 17, a male aged 70 years, with granulomatous anterior uveitis, suffered from lupus vulgaris and psoriasis. Chest radiographs showed emphysema only; he had a positive differential agglutination test for rheumatoid arthritis, but did not attend for further examination.

No effort was made to record all traces of possible previous tuberculous chest disease, but obvious radiographic evidence of old apical lesions was recorded in fourteen patients, calcified hilar lesions in five patients, and old pleural reactions at the lung bases in five patients. There was a slight tendency, not statistically significant, for the apical and hilar lesions to occur more commonly in anterior uveitis of granulomatous and doubtful types, and this was more marked in the basal pleural lesions, so that when all the patients with old lung lesions were considered, the increased incidence in these types of uveitis (twelve in 57 radiographs) was significant $\left(\chi^{2}=5 \cdot 1\right.$; $P=0.03$ ) when compared with the remainder of the series (twelve in 145 radiographs). There was, however, no certainty that all these lesions, especially the basal ones, were in fact tuberculous.

The distribution of the Mantoux reactions, excluding the three patients with definite or probable sarcoidosis, is shown in Table XIV (overleaf); there was an increased incidence of negative reactions in patients with granulomatous anterior uveitis of no known association, but this was not statistically significant; in none of these patients was the clinical picture suggestive of sarcoidosis.

There was a tendency, again not significant, for an increased incidence of positive Mantoux reactions to $0.01 \mathrm{mg}$. in patients with non-granulomatous anterior uveitis; this was due almost entirely to the high proportion of such reactions in the age group 21-40 years (sixteen out of the seventeen patients), which was significantly higher $\left(\chi^{2}=4.6 ; P=0.04\right)$ than that in the remainder of the age group ( 36 out of 57 ); it was still significantly high if the relatively 
TABLE XIV

MANTOUX REACTION

\begin{tabular}{|c|c|c|c|c|c|c|c|c|c|}
\hline & & & & & terior Uve & eitis & & & \\
\hline & $\begin{array}{l}\text { sociation } \\
\text { r Genera }\end{array}$ & $\begin{array}{l}\text { with Local } \\
\text { Disease** }\end{array}$ & $\begin{array}{c}\text { Kerato- } \\
\text { uveitis }\end{array}$ & Granulo- & \begin{tabular}{|c|} 
Non- \\
granulo-
\end{tabular} & Doubtful & $\begin{array}{c}\text { Posterior } \\
\text { Uveitis }\end{array}$ & $\begin{array}{c}\text { Pan- } \\
\text { uveitis }\end{array}$ & Tota \\
\hline & & No. Tested & 11 & 2 & 2 & - & - & - & 15 \\
\hline Known & $\begin{array}{l}\text { rheum- } \\
\text { atic }\end{array}$ & $\begin{array}{l}\text { Negative } \\
\text { + to } 0.1 \mathrm{mg} \text {. } \\
\text { t to } 0.01 \mathrm{mg} \text {. }\end{array}$ & $\begin{array}{l}3 \\
1 \\
7\end{array}$ & $\frac{1}{1}$ & $\overline{\overline{2}}$ & 二 & E & E & $\begin{array}{r}4 \\
1 \\
10\end{array}$ \\
\hline tion & & No. Tested & 2 & 1 & 21 & 8 & 1 & - & 33 \\
\hline & $\begin{array}{c}\text { Rheum- } \\
\text { atic }\end{array}$ & $\begin{array}{l}\text { Negative } \\
\text { + to } 0.1 \mathrm{mg} . \\
\text { t to } 0.01 \mathrm{mg} \text {. }\end{array}$ & $\frac{-}{2}$ & $\overline{-}$ & $\begin{array}{r}2 \\
5 \\
14\end{array}$ & $\begin{array}{l}-3 \\
5\end{array}$ & $\underline{1}$ & E & $\begin{array}{r}3 \\
8 \\
22\end{array}$ \\
\hline & & No. Tested & 16 & 42 & 56 & 15 & 28 & 3 & 160 \\
\hline $\begin{array}{l}\text { No K } \\
\text { Assoc }\end{array}$ & $\begin{array}{l}\text { nown } \\
\text { iation }\end{array}$ & $\begin{array}{l}\text { Negative } \\
\text { + to } 0.1 \mathrm{mg} . \\
\text { + to } 0.01 \mathrm{mg} .\end{array}$ & $\begin{array}{r}3 \\
3 \\
10\end{array}$ & $\begin{array}{r}10 \\
8 \\
24\end{array}$ & $\begin{array}{r}6 \\
8 \\
42\end{array}$ & $\begin{array}{r}2 \\
3 \\
10\end{array}$ & $\begin{array}{r}5 \\
6 \\
17\end{array}$ & $\begin{array}{r}1 \\
2 \\
-\end{array}$ & $\begin{array}{r}27 \\
30 \\
103\end{array}$ \\
\hline
\end{tabular}

* Three patients with sarcoidosis are excluded

increased proportion of negative reactions in granulomatous anterior uveitis was allowed for by omitting this entire group $\left(\chi^{2}=4 \cdot 1 ; P<0.05\right)$. The distribution of the Mantoux reaction is shown in the Figure; the patients with rheumatic disease show an increased incidence of positive reactions, as have been described in ankylosing spondylitis by Robinson (1940), but this increase was not so marked as in non-granulomatous anterior uveitis of no known association. In the series as a whole, there was a general tendency

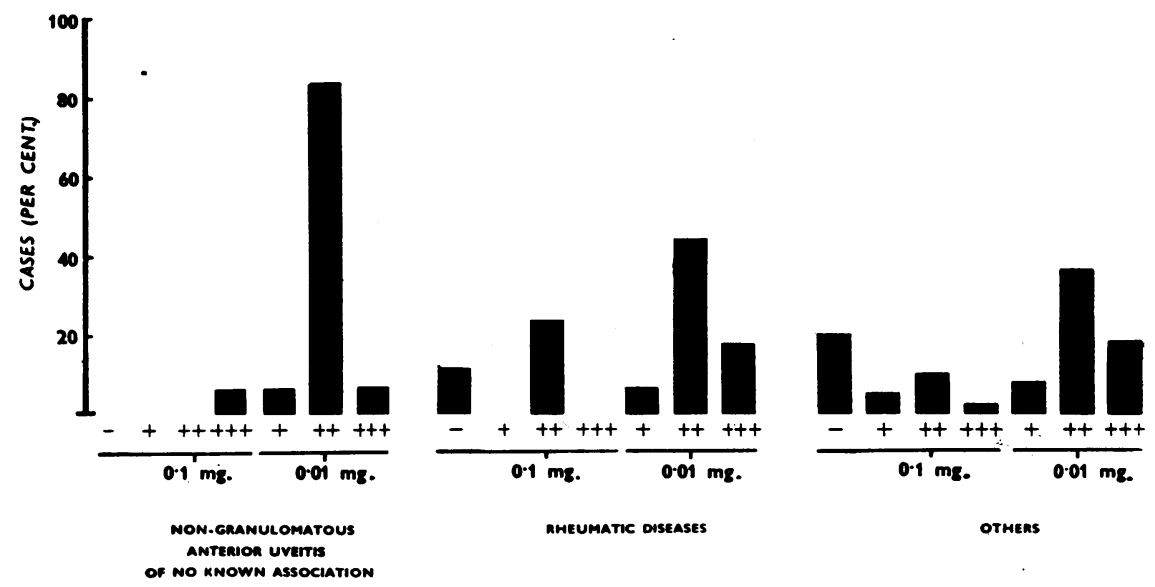

FIGURE.-Mantoux reaction in patients aged 21 to 40 years (excluding one patient with probable sarcoidosis). 
to a higher proportion of positive reactions in males, but the high incidence of positive Mantoux reactions to $0.01 \mathrm{mg}$. in non-granulomatous anterior uveitis of no known association in the age group 21-40 years occurred in both sexes (in twelve of thirteen males, and in all of the four females).

\section{Periarteritis Nodosa}

This disease was suspected in two patients described elsewhere (Stanworth and Sharp, 1956), one with posterior uveitis and one with granulomatous anterior uveitis; the latter had no upper respiratory tract infection and appeared to be edentulous, but was not seen by the dental surgeon.

\section{ERYTHEMA CirCINATA}

A female aged 48 years with non-granulomatous anterior uveitis had had recurrent erythema circinata since the age of 18 years; she had throat infection with Streptococcus haemolyticus; the Mantoux reaction was negative.

\section{ToxopLASMOSIS}

The dye test for toxoplasmosis, using the modification described by Beverley and Beattie (1952), was carried out on seventeen patients in this series. Nine had posterior uveitis, which was generalized in four, focal in three, and associated with retinal perivasculitis in two; one of the latter, described by Stanworth and Sharp (1956), had Reiter's disease. The small number of tests was due to the fact that experience of the dye test in Manchester since the end of 1952 had revealed very few patients with a positive test; following the report by Woods, Jacobs, Wood, and Cook (1954) that 25 per cent. of cases of granulomatous uveitis appeared to be due to toxoplasmosis, routine testing of patients was started in this series in April, 1954, but was largely confined, in order to conserve both time and material, to those patients who appeared most likely to have positive reactions, i.e. those with granulomatous posterior uveitis or pan-uveitis; the ten patients with posterior or pan-uveitis who had the dye test carried out comprise twothirds of such patients seen since that date.

The test was positive to a titre of at least $1 / 16$ in a girl aged 14 years with focal choroidoretinitis, and to a titre of $1 / 4$ in a male aged 58 years with recurrent generalized posterior uveitis since 1915, who had also suffered from recurrent amoebiasis and from strongyloides infection. In the remaining eight patients, the dye test was negative, as it was in five patients with non-granulomatous anterior uveitis (two of whom had evidence of ankylosing spondylitis, one with radiographic spinal changes), in one with granulomatous anterior uveitis, and in two with kerato-uveitis (one of whom had herpes zoster ophthalmicus).

These results differ greatly from those reported by Smith and Ashton (1955) and by Perkins, Smith, and Schofield (1956); in both these series, the tests had been done by the same method but in a different laboratory (Department of Bacteriology, University of Sheffield); in view of the reported 
erratic value of the results of the dye test on individual sera (Lelong and Desmonts, 1952; Goldman, 1956), the tests were repeated in Sheffield on stored sera from sixteen of the eighteen patients (in two patients (one of whom had the titre of 1 in 16) the sera had deteriorated and were useless for further testing). The results were quite different from those originally obtained: in six patients with generalized or focal choroidoretinitis, the test was positive at titres of 1 in 58, 1 in 40 (previously 1 in 4), 1 in 20,1 in 16, 1 in 13, and 1 in 5; in perivasculitis, it was positive at titres of 1 in 20 (the patient with Reiter's disease) and 1 in 19; in non-granulomatous anterior uveitis, it was positive in two patients with titres of 1 in 14 (ankylosing spondylitis without radiographic changes) and 1 in 6 (ankylosing spondylitis with radiographic spinal changes), and negative in two; in the patient with granulomatous anterior uveitis it was negative; in both patients with keratouveitis it was positive, with titres of 1 in 100 (the patient with herpes zoster ophthalmicus) and 1 in 18 . The test was negative in a patient with panuveitis who was not tested in Manchester. The complement-fixation test was only possible in five patients (dye test titres 1 in 58,1 in 20,1 in 13, 1 in 6 and $<1$ in 4), and was negative in all five.

\section{LEPTOSPIROSIS AND BRUCELLOSIS}

No suggestion of these diseases was obtained from the history of any patients; the leptospira agglutination test was negative in eighteen patients.

\section{ALLERGY}

A history of allergy was obtained in nine patients: four had asthma (one also with allergic dermatitis), four had hay fever, and one gave a history of allergy to penicillin. One patient with severe chronic kerato-uveitis had skin tests for allergy and was found to be markedly sensitive to inhalants, but desensitization and antihistamine therapy did not appear to affect the course of the disease. One patient had atypical spondylitis, one had posterior uveitis, and five had anterior uveitis (non-granulomatous in one, of doubtful type in one, and granulomatous in three, two of the latter being associated with infection). It appears, then, that the overall incidence is probably not appreciably different from that in the general population, and an allergic history was not associated with any one type of uveitis.

\section{VIRUs DisEASES}

In addition to the sixteen patients with uveitis of definite virus origin (herpes zoster ophthalmicus and dendritic ulceration), uveitis was associated with superficial punctate keratitis in six patients, one of whom had Reiter's disease with radiographic evidence of spinal changes.

Evidence of possible preceding abacterial conjunctivitis or keratitis, such as Bennett (1955) considers to be due to virus infection, was obtained in twelve patients with anterior uveitis, one of whom had radiographic evidence of ankylosing spondylitis; of the remainder, the uveitis was granulomatous 
in two patients, non-granulomatous in five, and of doubtful type in four. Four patients gave a history of mild ocular trauma, such as Bennett (1955) considers may precipitate a virus infection. One had ankylosing spondylitis, two others had non-granulomatous anterior uveitis, and one had granulomatous anterior uveitis associated with parodontal sepsis. On this basis, the maximum incidence of diagnosable virus infection in anterior uveitis was 9 per cent. (sixteen in 170 patients); if kerato-uveitis is included, the incidence rises to 19 per cent. in anterior uveitis (38 in 205 patients) or to 16 per cent. in the whole series. This is much lower than the figure of 38 per cent. given by Bennett (1955), which obviously includes many patients in whom a virus origin of uveitis is far from proved.

\section{Serum Proteins and Erythrocyte Sedimentation Rate}

Serum proteins were estimated in 204 patients, and a globulin content of more than $3.5 \mathrm{mg}$. per cent. was noted in 41 patients. One of the systemic diseases already discussed, including the rheumatic diseases, could reasonably be held responsible in 25 of these 41 patients; one was pregnant; one had uveitis due to rupture of the lens capsule; repetition of the test in four patients gave a normal result. The highest serum globulin content in the remaining ten patients was $4 \mathrm{mg}$. per cent., and none of them had granulomatous anterior uveitis.

The erythrocyte sedimentation rate was measured in 207 patients, and was found to be raised in 67 patients. One of the diseases already discussed could reasonably be held responsible in 48 patients; there was no evidence of serious systemic disease in the remaining patients, and there was no obvious tendency for them to have any particular variety of uveitis.

\section{Uveitis possibly due to Systemic Diseases}

In addition to the patients already described with a known local or general disease, eleven may also have had a systemic disease, other than spondylitis, related to their uveitis, namely three -with venereal disease (Cases 8, 9, and 12), one with venereal disease and active tuberculosis (Case 10), one with sarcoidosis (Case 14), two with possibly active tuberculous lesions (Cases 16 and 17), one with diabetes and terminal uraemia (Case 13), two with polyarteritis nodosa, and one with erythema circinata. The possible importance of toxoplasmosis will be discussed later. Ten of the eleven patients had anterior uveitis (which was granulomatous in four, non-granulomatous in three, and of doubtful type in three), and one had posterior uveitis. In addition, six patients with granulomatous anterior uveitis had radiological evidence of inactive chest lesions that could have been tuberculous; these were apical in two, hilar in two, and basal in two. 


\section{DISCUSSION}

\section{BY \\ A. STANWORTH}

\section{RHEUMATIC DisEASES}

Ankylosing spondylitis and atypical forms of spondylitis are the largest single group of systemic diseases with which uveitis has been found to be associated in this survey (Stanworth and Sharp, 1956; Stanworth, 1956); these forms of spondylitis are relatively rare, and an incidence of 37 radiologically proved cases in 237 patients is undoubtedly of great significance. It is therefore surprising that so little interest has been taken in this association; Woods (1956b), for example, in an exhaustive manual designed for teaching purposes, omits all mention of the rheumatic diseases, and Dekking (1954) considers the association to be no more than an interesting coincidence. Both these authors believe that streptococcal infection is aetiologically related to non-granulomatous uveitis; if this be the case, there are three possible assumptions regarding the rheumatic disease:

(i) Non-granulomatous uveitis and rheumatic disease are associated by chance. This is unlikely in view of the closeness of the association, for at least two-fifths and possibly one-half of the males with non-granulomatous anterior uveitis had spondylitis (Stanworth and Sharp, 1956).

(ii) Non-granulomatous uveitis and rheumatic disease are both responses to streptococcal infection. This is affirmed by Woods (1953), largely on the evidence of skin sensitivity tests with streptococcal vaccines in non-granulomatous uveitis and of streptococcal agglutination and precipitin titres in rheumatoid arthritis. In common with other American authors (Bauer, 1939; Boland and Present, 1945; Hench, Slocumb, and Polley, 1947), he presumably considers ankylosing spondylitis to be a variant of rheumatoid arthritis involving the spine; in Great Britain, however, it is considered to be a separate disease, and the significant association with non-granulomatous anterior uveitis, in contrast to the lack of marked association between classical rheumatoid arthritis and any form of uveitis, is in accordance with this view. According to Buckley (1955), ankylosing spondylitis is probably of infective origin, the focus probably being always pelvic but frequently not venereal. Buckley considered infection from the intestine to be the source in many cases; West (1949) considered that the disease might be related to a iocal metabolic defect in articular structures subjected to continuous stress, with heredity as a major aetiological factor. Reiter's disease, which in its later stages may give a picture indistinguishable from ankylosing spondylitis (Ford, 1953), may also be due to pelvic infection, either urethral or intestinal, possibly by a virus (Harkness, 1950). In any case, there is a considerable body of opinion that there is no acceptable evidence that infection is directly or indirectly the cause of rheumatoid arthritis (Duthie and Davidson, 1955); and in ankylosing spondylitis the streptococcal agglutination and precipitin titres are normal (Levinthal, 1938), as is the antifibrinolysin titre (Perry, 1940).

(iii) These rheumatic diseases, though not in themselves related to streptococcal 
infection, may predispose the patient to uveitis due to such infection. This would lead one to expect a high incidence of streptococcal infection in non-granulomatous uveitis, but that has not been found to be the case in this survey in patients either with or without rheumatic disease.

There remains the possibility that a connexion exists between non-granulomatous uveitis and a factor common to the various forms of spondylitis, perhaps related to the spinal involvement. Such a factor might be present only in patients with rheumatic disease, or in many other patients with nongranulomatous anterior uveitis; in favour of the former is the fact that spinal arthritis affects mainly males, whereas the non-rheumatic patients with nongranulomatous anterior uveitis showed no particular sex distribution. This suggests that there may be two factors in the aetiology of this type of uveitis, one affecting mainly males and associated with spinal involvement, and a second unrelated to rheumatic disease and not sex-linked. Whether or not this supposition is true, it remains of importance to pay considerable attention to the connexion between uveitis and rheumatic disease.

Rheumatic Fever.-The failure to find any relationship between rheumatic fever and uveitis, in spite of the association between granulomatous anterior uveitis and Streptococcus haemolyticus infection, may be due to the fact that rheumatic fever is usually associated with Group-A Streptococcus haemolyticus infection (Horder and Bywaters, 1955), whereas the association found in the present survey was mainly with streptococci not in Group A.

\section{TUBERCULOSIS}

The proportion of uveitis ascribed to tuberculosis has varied widely with different observers, but there has been a tendency to consider it of less and less importance in the last 20 years; thus Guyton and Woods (1941) found that 79 per cent. of granulomatous uveitis was due to tuberculosis, Woods and Guyton (1944) 52 per cent., and Woods, Jacobs, Wood, and Cook (1954) only 23 per cent. The criteria for the diagnosis of ocular tuberculosis (Woods 1956b) are still largely dependent on the exclusion of other causes; moreover, of the more positive indications of tuberculosis, focal ocular reactions to tuberculin could be non-specific, and an association of uveitis with deep scleritis or sclero-keratitis may be due to other causes-for example, to nodular rheumatoid arthritis. It appears therefore, that the role of tuberculosis is still very much in doubt; in the present series, it was impossible to be certain that any patient had tuberculous uveitis, and only eight patients with granulomatous anterior uveitis or pan-uveitis had sufficient radiographic evidence of either active or old chest lesions to justify comment by the radiologist.

In patients without proved rheumatic disease or any known cause for their uveitis, the association between non-granulomatous anterior uveitis and a markedly positive Mantoux reaction is of considerable interest, particularly in view of the reported sensitivity of this type of patient to skin tests with 
streptococcal vaccines (Woods, 1950, 1953, 1956a). This suggests that both these skin reactions may be due to a non-specific tendency of these patients to show markedly positive skin tests to a variety of agents, and is reminiscent of the similar tendency to a high level of reaction to tubęrculin among patients with ankylosing spondylitis (Robinson, 1940).

\section{TOXOPLASMOSIS}

The evidence that toxoplasmosis is a cause of uveitis is mainly statistical. Toxoplasma antibodies are found more frequently in persons who have uveitis than in those who have not. Thus Perkins and Beverley (1957) found toxoplasma dye test antibodies present to a titre of 1 in 4 or more in over 60 per cent. of patients with uveitis but in only 30 per cent. of normal people. The difference was particularly marked in the younger age group. Under the age of 20 years toxoplasma antibodies were found in 60 per cent. of patients with uveitis and in less than 10 per cent. of others. The statistical evidence is supported by the isolation of toxoplasma from the retina and choroid (Jacobs, Fair, and Bickerton, 1954), and by its demonstration in histological sections (Wilder, 1952a, b; Duke-Elder, Ashton, and Brihayevan Geertruyden, 1953).

While serological evidence has been of great value in establishing statistically that toxoplasmosis is a cause of uveitis, it is of much less value in making a diagnosis of toxoplasmic uveitis in an individual patient. A negative result, at any rate from tests carried out in Sheffield, can be taken to exclude it, but a positive result, even to a high titre, does not prove it. All that can be said is that in a child the presence of antibodies, particularly if they be of high titre, makes it very likely that the uveitis is due to toxoplasmosis. In an adult a positive test, especially in high titre, obviously increases the chance of the condition being toxoplasmic, but the whole clinical picture has to be taken into account.

Jacobs, Naquin, Hoover, and Woods (1956) indicate that a dye test of 1 in 64 or more may be taken as significant; but Beattie (1957) found that 12 per cent. of normal adults in rural areas and 5 per cent. in urban areas in Great Britain had antibodies to this titre. Smith and Ashton (1955) ascribed equal significance to a positive dye test at any level; in support of this, it may be mentioned that Jacobs, Cook, and Wilder (1954) found titres of less than 1 in 64 in cases of ocular toxoplasmosis. Perkins, Smith, and Schofield (1956) think that toxoplasmosis is probably the cause of the uveitis in 25 per cent. of patients with any level of toxoplasma antibody. This applies most strongly to patients with posterior uveitis, in whom positive results in low titres occurred much more commonly than in the general population, and it appeared unlikely that cases of generalized uveitis were due to toxoplasmosis.

In the present series, the serum of only one patient had antibodies to a titre of 1 in 64 and in her case the kerato-uveitis was undoubtedly due to 
herpes zoster ophthalmicus. Three patients with focal choroidoretinitis approached this level: one with a titre of at least 1 in 16 (tested in Manchester), and two with titres of 1 in 58 and 1 in 40 (tested in Sheffield).

The variations in titre obtained in different tests on the same sera, together with the occurrence of positive tests in herpes zoster ophthalmicus and ankylosing spondylitis in the present series and in that of Davenport (1955), indicate that, in any individual patient, the interpretation of low titres can be difficult or impossible.

\section{AlLERgY}

The failure to find any obvious association between uveitis and hay fever or asthma does not necessarily mean that other forms of allergy may not be of importance; there may well be a fundamental distinction between the immediate allergic response, such as hay fever and urticaria, and the delayed responses, such as bacterial allergy (Pickering, 1952).

\section{FOCAL INFECTION}

The strong association of parodontal, nasal sinus, and Streptococcus haemolyticus infections with granulomatous anterior uveitis was mainly with the very chronic type, and with those patients in whom pan-uveitis could not be excluded. This is of interest since, as we have already noted, Perkins, Smith, and Schofield (1956) found that it was unlikely that cases of generalized uveitis are due to toxoplasmosis, and the absence of tests for toxoplasmosis in these patients is therefore probably of little significance.

If it is considered that focal infection occurs only by chance in those patients whose uveitis was possibly due to systemic disease (including those with radiological evidence of old chest lesions), or who had heterochromic cyclitis or the Vogt-Koyanagi syndrome, there still remain, in patients fully investigated, sixteen patients with infection out of 22 with granulomatous anterior uveitis of no known association, compared with 51 out of 122 patients in the remnants of the series; this difference is still significant $\left(\chi^{2}=6.0 ; P<0.02\right)$; it appears likely, therefore, that the association with infection is of more importance than the rather nebulous connexion with systemic diseases in many of these patients.

The finding of a strong association between focal infection and granulomatous anterior uveitis is contrary to the experience of Woods $(1953,1956 \mathrm{a})$, who found foci of infection in only 30 per cent. of granulomatous uveitis compared to 54 per cent. of non-granulomatous uveitis; there are, however, several factors which may explain the difference.

In the first place, the criteria of significant focal infection in the present series (namely parodontal, nasal sinus, and Streptococcus haemolyticus infection) have been evolved as a result of analysis of the series itself, and may well be very different from those employed by Woods.

Secondly, the classification of uveitis is different, for Woods takes no 
account, in his subdivision into granulomatous and non-granulomatous, of the subdivision into anterior and posterior, of the presence or absence of rheumatic disease or other known associations, or of age or sex.

Thirdly, it is probable that the patients reviewed by Woods did not form a random series, since they were "referred to the Wilmer Institute for study, to determine, if possible, the cause of the uveitis". They may therefore have included a higher proportion of patients with a poor prognosis or recurrent attacks. For example, Woods states that, in non-granulomatous uveitis, "recurrences, spaced at intervals from a few weeks to many months, are the rule rather than the exception" (Woods, 1953). In contrast to this, only seven of the 26 patients with rheumatic disease in the present series, and twelve of the sixty without such disease, could be said, on the basis of their previous history and subsequent progress during a follow-up period averaging 33 months, to have recurrences at intervals measured in months, rather than in years; and in almost half the patients with rheumatic disease and twothirds of those without such disease, the attack of non-granulomatous uveitis for which they originally attended was a completely isolated one. This difference in the frequency of recurrent attacks does not, however, fully explain the disparity in the findings, since there was no apparent difference, in the present series, in the incidence of focal infection between those patients with and those without frequent recurrences.

Woods (1956b) takes the view that there is no evidence that foci of infection in the body can produce an effect on the uvea except by a hypersensitivity phenomenon. He has himself pointed out, however, "that bacteria do constantly enter the blood stream in small numbers in normal persons. For example, colon bacilli can often be cultivated from the portal vein; pyelitis develops with amazing regularity if there is an obstruction to the ureter, and the source of infection can be conclusively traced to intermittent bacteraemia, the kidney being infected only because predisposed by the local condition" (Guyton and Woods, 1941). These facts indicate that bacterial metastasis, with or without superadded allergic reactions, cannot be ruled out. Absence of positive blood cultures in uveitis is not conclusive evidence against this, since negative cultures are common, even in known bacteraemia such as subacute bacterial endocarditis.

Woods (1956b) also considers that uveitis related to focal sepsis is always of a non-granulomatous type; a granulomatous type of reaction can, however, occur as a result of infection with pyogenic organisms, as may be seen in vegetating pyoderma and the granulomatous lesions of parodontal sepsis (Montgomery, 1953).

If bacterial metastasis be an aetiological factor, the failure to find an association between granulomatous anterior uveitis and periapical sepsis suggests that it is the presence of a relatively large area of infection which is of importance, rather than the more compact infection found in periapical disease, even though the latter may contain pus under pressure. The failure 
to find any localization of parodontal infection to the upper jaw on the same side as the uveitis also supports a connexion via the blood stream rather than via the nasal sinuses or the lymphatic glands. The duration of the infection may also be of importance; this would explain why the associations with nasal sinus and Streptococcus haemolyticus infections were more marked in elderly people, whereas parodontal sepsis exerted its main influence before the age at which the teeth are likely to be lost.

It is not surprising that, in surveys of infection in uveitis as a whole (Guyton and Woods, 1941 ; Bennett, 1955), no obviously increased incidence of focal sepsis was found, for it is only in granulomatous anterior uveitis and pan-uveitis that the association has been found in this survey, and these comprised only 23 per cent. of the whole. Moreover, it is possible that upper respiratory tract infections may, like chronic bronchitis, be more common in the north-west region of England, due perhaps to the high humidity accompanied by smoke (Goodman, Lane, and Rampling, 1953), so that infection as a cause of granulomatous anterior uveitis may be of less significance outside this area.

The failure to find an association between streptococcus infection and nongranulomatous anterior uveitis does not, in itself, necessarily override the evidence obtained from skin tests and from studies of the anti-streptolysin titres; nevertheless, as we have seen, these studies may be misleading (Otten and Westendorp Boerma, 1954); moreover Woods (1953a) considered that Streptococcus haemolyticus belonging to Lancefield Group-A is of considerable importance, in which case it is surprising that there is no obvious connexion between uveitis and rheumatic fever, a disease which is undoubtedly associated with raised anti-streptolysin titres following infections with this organism (Gibson, 1955; Horder and Bywaters, 1955).

\section{Endogenous Uveitis}

This investigation has not thrown any new light on the aetiology of keratouveitis, except to confirm that occasionally uveitis may be associated with transient superficial punctate keratitis, possibly of virus origin, and sometimes with Reiter's disease. If kerato-uveitis be excluded, together with those patients suffering from herpes zoster ophthalmicus, sympathetic ophthalmia, and rupture of the lens capsule, 197 patients with "endogenous" uveitis remain. Associations with general disease are shown in Table XV (overleaf), a patient with more than one association being included only under that disease which appears first in the Table. Had all the patients been fully investigated, the number with no known association could be expected to be diminished to some extent, but almost half the total number would still remain with no known association.

Of these, almost half had non-granulomatous anterior uveitis; it is suggested that further attention should be paid to the relationship of this type 27 
TABLE XV

ENDOGENOUS UVEITIS*

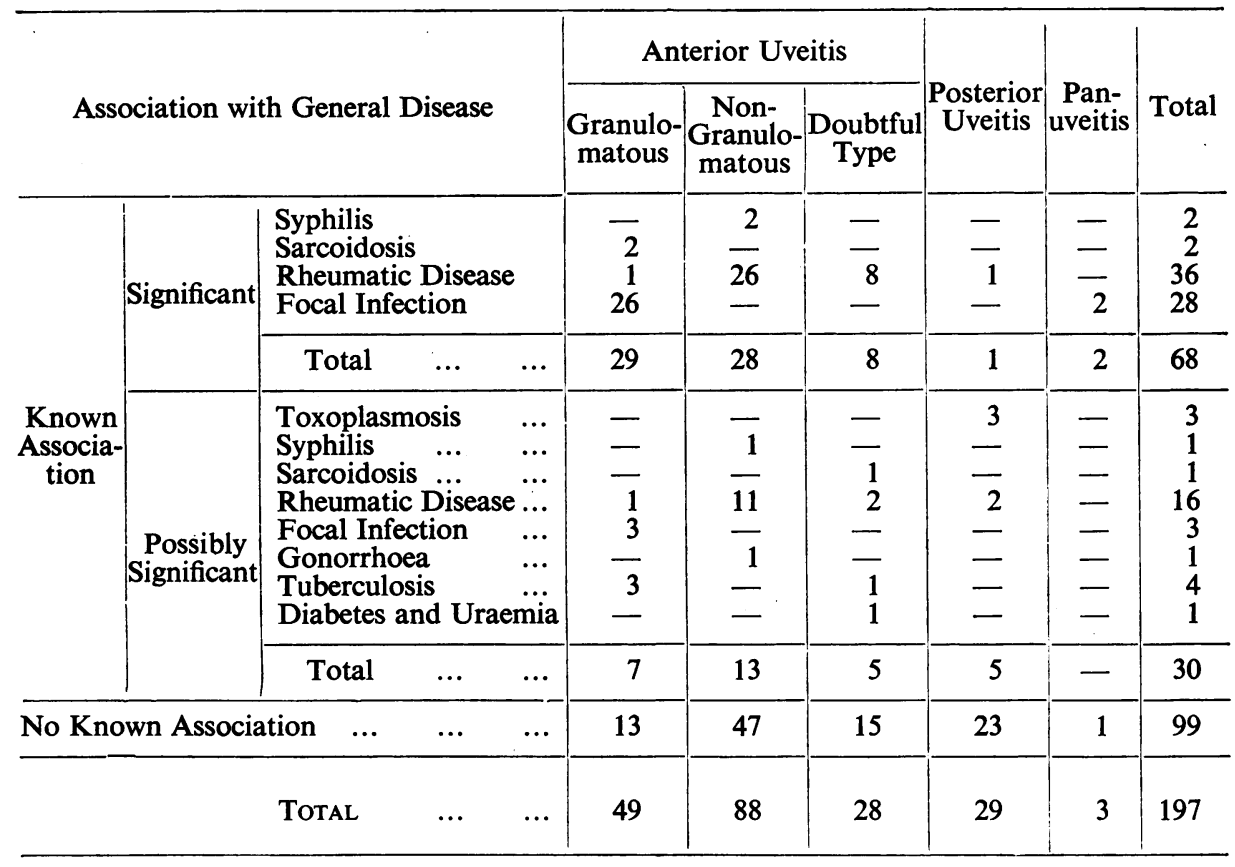

* Patients with kerato-uveitis, herpes zoster ophthalmicus, sympathetic ophthalmitis, and ruptured lens capsule

of uveitis to rheumatic diseases and to the tendency to react excessively to a variety of agents (e.g. tuberculin, streptococcal vaccines).

In granulomatous anterior uveitis and pan-uveitis, further studies are obviously needed to confirm the suggested causal importance of focal infection, and to study the organisms involved in the parodontal and nasal sinus infections.

In posterior uveitis, toxoplasmosis may account for a number of the patients not so far definitely diagnosed, but there may well be regional variations in the incidence of the disease, as there are in such causes of uveitis as brucellosis and leptospirosis.

The correlations established between non-granulomatous anterior uveitis and rheumatic disease on the one hand, and between granulomatous anterior uveitis, pan-uveitis, and focal infection on the other hand, tend to suggest that it is of value to distinguish between the granulomatous and nongranulomatous types of uveitis; nevertheless, the conclusions reached in this survey would be substantially unaltered if the uveitis had been classified simply into acute and chronic, and it is undoubtedly true that the distinction between granulomatous and non-granulomatous types is not an absolute one (Ashton, 1954). 


\section{Summary}

(1) 237 consecutive patients with uveitis were investigated.

(2) Granulomatous anterior uveitis was found to be associated with parodontal and nasal sinus infections, and with the presence of Streptococcus haemolyticus in nasal and throat cultures. The association was more marked in those patients in whom the uveitis was obviously of a chronic type, and in whom pan-uveitis could not be excluded. The response to treatment was not inconsistent with a causal connexion.

(3) Positive cultures for pneumococci were associated with anterior uveitis in younger patients; a particular association with the granulomatous type was less certain. No definite evidence of other significant infections was found.

(4) The pathogen selective test was of no value in predicting which organisms were related to uveitis.

(5) Non-granulomatous anterior uveitis was associated with strongly positive Mantoux reactions; this may be evidence of a general non-specific tendency to react to a variety of agents. There may be two factors in the aetiology of this type of uveitis, one affecting mainly males and associated with various forms of spondylitis, and a second unrelated to rheumatic disease and not sex-linked.

(6) The importance ascribed to toxoplasmosis depends on the criteria employed; venereal diseases, tuberculosis, and sarcoidosis accounted for only a small number of cases; diabetes was largely coincidental.

I am greatly indebted to Dr. F. B. Jackson, who was responsible for the routine laboratory tests, the pathogen selective tests, and tests for toxoplasmosis; to Dr. J. K. A. Beverley for repeating the toxoplasmosis tests in the Department of Bacteriology, University of Sheffield; to Prof. C. P. Beattie for considerable help with the section on toxoplasmosis; to Mr. K. Harrison for the E.N.T. examinations; to Dr. J. C. Broom for the leptospira agglutination tests; to Dr. R. Ollerenshaw and the staff of the Medical Illustration Department for reproducing the Figure; and to Mr. O. M. Duthie for his advice and encouragement.

\section{REFERENCES}

Alvaro, M. E. (1954). Ophthalmologica (Basel), 127, 85.

AMSLER, M. (1955). In A. Sorsby, "Modern Trends in Ophthalmology", 3rd series, p. 137. Butterworth, London.

Ashron, N. (1954). "Conc. Ophthal. 1954. Canada, U.S.A. Acta", vol. 2, p. 1214. Univ. Toronto Press.

BeAtTIE, C. P. (1957). Trans. roy. Soc. trop. Med. Hyg., 51, 96.

BAUER, W. (1939). New Engl. J. Med., 221, 524.

BEDELL, A. J. (1925). Dental Cosmos, 67, 990.

BENEDICT, W. L. (1920). Amer. J. Ophthal., 3, 860.

BENNETT, G. (1955). British Journal of Ophthalmology, 39, 727.

Beverley, J. K. A., and Beattie, C. P. (1952). J. clin. Path., 5, 350.

Boland, E. W., and Present, A. J. (1945). J. Amer. med. Ass., 129, 843.

BuCKLEY, C. W. (1955). In W. S. C. Copeman, "Textbook of the Rheumatic Diseases", 2nd ed., p. 326. Livingstone, Edinburgh.

Cantou, J. P. (1942). S. Afr. dent. J., p. 169.

DAVENPORT, R. C. (1956). Proc. roy. Soc. Med., 49, 19.

DeKkING, H. M. (1954). Trans. ophthal. Soc. U.K., 74, 503.

DOGGART, J. H. (1951). Ann. roy. Coll. Surg. Engl., 9, 333.

DUKE-ELDER, S. (1940). "Text-book of Ophthalmology", vol. 3, p. 2157. Kimpton, London. , Ashton, N., and Brihaye-VAn GeERTRUYDEN, H..(1953). British Journal of Ophthalmology, 37, 321. 
Duthie, J. J. R., and Davidson, L. S. P. (1955). In W. S. C. Copeman, "Text-book of the Rheumatic Diseases", 2nd ed., p. 170. Livingstone, Edinburgh.

ForD, D. K. (1953). Ann. rheum. Dis., 12, 177.

FrançoIs, J. (1950). Ann. Oculist. Paris, 183, 745.

GIBson, H. J. (1955). In W. S. C. Copeman, "Text-book of the Rheumatic Diseases', 2nd ed., p. 539 . Livingstone, Edinburgh.

Goldman, M. (1956). J. clin. Path., 9, 55.

Goodman, N., LANE, R. E., and Rampling, S. B. (1953). Brit. med. J., 2, 237.

GuYTon, J. S., and Woods, A. C. (1941). Arch. Ophthal. (Chicago), 26, 983.

Hallet, J. W., Leopold, I. H., and INWALD, S. (1956). A.M.A. Arch. Ophthal., $55,313$.

HARKNESS, A. H. (1950). "Non-gonococcal Urethritis", p. $99 . \quad$ Livingstone, Edinburgh.

HARLEY, D. (1952). Trans. ophthal. Soc. U.K., 72, 419.

Hench, P. S., Slocumb, C. H., and Polley, H. F. (1947). Med. Clin. N. Amer., 31, 879.

Horder, LORD, and BYWATERS, E. G. L. (1955). In W. S. C. Copeman, "Text-book of the Rheumatic Diseases", 2nd ed., p. 123. Livingstone, Edinburgh.

JACOBs, L., COOK, M. K., and WILDER, H. C. (1954). Trans. Amer. Acad. Ophthal. Otolaryng., $\mathbf{5 8 ,} 193$.

, FaIR, J. R., and Bickerton, J. H. (1954). A.M.A. Arch. Ophthal., 51, 287.

, Falr, J. R., and Bickerton, J. H. (1954). A.M.A. Arch. Ophthal., 51, 287.

Lelong, M., and Desmonts, G. (1952). C.R. Soc. Biol. Paris, 146, 207.

LeOPOLD, I.' H., and Dickinson, T. D. (1954). Trans. Amer. Acad. Ophthal. Otolaryng., $58,210$.

LeVINTHAL, W. (1938). "Proc. Int. Cong. Rheum. Hydrol. (London and Oxford) and of the Bicentenary Congress on Chronic Rheumatism (Bath)", p. 345.

Montgomery, G. L. (1953). "Pathology for Students of Dentistry". Livingstone, Edinburgh.

Nectoux, R. (1947). Bull. Soc. Ophtal. Paris, p. 599.

OtTEN, H. A., and Westendorp BoERMA, F. (1954). Acta med. scand., 149, 55.

Perkins, E. S., and Beverley, J. K. A. (1957). Proc. roy. Soc. Med., (in the press). Smith, C. H., and SCHOFIELD, P. B. (1956). British Journal of Ophthalmology, $40,577$.

Perry, C. Bruce (1940). Ann. rheum. Dis., $2,147$.

Pickering, G. W. (1952). Brit. med. J., 2, 1207.

RoBInson, G. (1940). Ann. rheum. Dis., 2, 41.

Rosenow, E. C. (1915). J. infect. Dis., 17, 403.

SCHöne, R., and STEEN, E. (1951). Acta ophthal. (Kbh.), 29, 201.

SMith, C., and AsHTON, N. (1955). British Journal of Ophthalmology, 39, 545.

StANWORTH, A. (1956). Trans. ophthal. Soc. U.K., 76, 287.

-, and MCINTYRE, H. (1957). British Journal of Ophthalmology, 41, 385.

, and Sharp, J. (1956). Ann. rheum. Dis., 15, 140.

Vesterdal, E. (1951). Acta ophthal. (Kbh.), 29, 509.

WeST, H. F. (1949). Ann. rheum. Dis., 8, 143.

WIIDER, H. C. (1952a). A.M.A. Arch. Ophthal., 47, 425. (1952b). Ibid., 48, 127.

Woods, A. C. (1942). Amer. J. Ophthal., 25, 1423. (1947). Ibid., 30, 257.

(1950). “Proc. XVI. Int. Congr. Ophthal., London", 1, 303. (1953). A.M.A. Arch. Ophthal., 50, 129. (1956a). Ibid., 56, 749.

(1956b). "Endogenous Uveitis". Williams and Wilkins, Baltimore.

, and GuYton, J. S. (1944). Arch. Ophthal. (Chicago), 31, 469.

—_, JACOBS, L., WoOD, R. M., and Cook, M. K. (1954). Amer. J. Ophthal., 37, 163. 